\title{
Shifting cultivation and hunting across the savanna-forest mosaic in the Gran Sabana, Venezuela: Facing changes
}

\author{
Izabela Stachowicz $^{\text {Corresp., 1, } 2 \text {, José R Ferrer-Paris }}{ }^{3,4}$, Ada Sanchez-Mercado ${ }^{4,5}$ \\ 1 Department of Biodiversity Studies and Bioeducation, University of Lodz, Łódź, Poland \\ Laboratorio de Biología de Organismos, Centro de Ecología, Instituto Venezolano de Investigaciones Científicas, Caracas, Venezuela \\ 3 Laboratorio de Ecología Espacial, Centro de Estudios Botánicos y Agroforestales, Instituto Venezolano de Investigaciones Cientificas, Maracaibo, \\ Venezuela \\ ${ }^{4}$ School of Biological, Earth and Environmental Sciences, University of New South Wales, NSW, Kensington, Australia \\ Ciencias Ambientales, Universidad Espíritu Santo, Guayaquil, Samborondón 092301, Ecuador \\ Corresponding Author: Izabela Stachowicz \\ Email address: izabela.stachowicz@biol.uni.lodz.pl
}

Background. Human encroachment and overexploitation of natural resources in the Neotropics is constantly increasing. Indigenous communities all across the Amazon, are trapped between a population rise and a hot debate about the sustainability of hunting rates. The Garden Hunting hypothesis states that shifting cultivation schemes (conucos) used by Amazon indigenous communities may generate favorable conditions, increasing abundance of small and medium wildlife species close to the 'gardens' providing game for indigenous hunters.

Methods. Here, we combined camera trap surveys and spatially explicit interview dataset on Pemón indigenous hunting scope and occurrence in a mosaic of savanna and forest in the Gran Sabana, Venezuela to evaluate to what extent the wildlife resource use corresponds to Garden Hunting hypothesis. We applied Royle-Nichols model and binomial regression in order to: 1) assess whether abundance of small and medium wildlife species is higher close to conucos and 2) evaluate whether hunters select hunting localities based on accessibility to wildlife resources (closeness to conuco) more than wildlife abundance.

Results. We find mixed evidence supporting the Garden Hunting hypothesis predictions. Abundance of small and medium species was high close to conucos but the pattern was not statistically significant for most of them. Pemón seem to hunt in locations dominated by forest, where species abundance was predicted to be higher, than in close vicinity to conucos. Hunting scope was focused on the most abundant species located close to the conuco (Cuniculus paca), but also in less abundant and unavailable species (Crax alector, Tapirus terrestris and Odocoileus virginianus).

Conclusions. Our research provided the first attempt of a systematic sampling survey in the Gran Sabana, generating a quantitative dataset that not only describes the current pattern of wildlife abundance, but sets the base-line to monitor temporal and spatial change in highland Amazon. We discuss the applicability of the estimates generated as a baseline as well as, environmental challenges imposed by economic, social and cultural changes such as mining encroachment for wildlife management. 
1 Shifting cultivation and hunting across the savanna-forest mosaic in the Gran Sabana,

2 Venezuela: Facing changes.

3

4 Izabela Stachowicz ${ }^{1,2}$, José Rafael Ferrer-Paris ${ }^{3,4}$, Ada Sánchez-Mercado ${ }^{3,5}$

5

$6{ }^{1}$ Department of Biodiversity Studies and Bioeducation, Faculty of Biology and Environmental

7 Protection, University of Łódź, Łódź, Poland

$8 \quad{ }^{2}$ Laboratorio de Biología de Organismos, Centro de Ecología, Instituto Venezolano de

9 Investigaciones Científicas, Caracas, Venezuela.

$10{ }^{3}$ University of New South Wales, School of Biological, Earth and Environmental Sciences,

11 NSW, Kensington 2052, Australia

$12{ }^{4}$ Laboratorio de Ecología Espacial, Centro de Estudios Botánicos y Agroforestales, Instituto

13 Venezolano de Investigaciones Científicas, Maracaibo, Venezuela.

$14{ }^{5}$ Ciencias Ambientales, Universidad Espíritu Santo, Samborondón 092301, Ecuador.

Corresponding Author:

Izabela Stachowicz

Banacha 1/3, Łódź 90 - 237, Poland

Email address: stachowicz.izabela@gmail.com 


\section{Abstract}

29

\section{Background.}

Human encroachment and overexploitation of natural resources in the Neotropics is constantly increasing. Indigenous communities all across the Amazon, are trapped between a population rise and a hot debate about the sustainability of hunting rates. The Garden Hunting hypothesis states that shifting cultivation schemes (conucos) used by Amazon indigenous communities may generate favorable conditions, increasing abundance of small and medium wildlife species close to the 'gardens' providing game for indigenous hunters.

\section{Methods.}

Here, we combined camera trap surveys and spatially explicit interview dataset on Pemón indigenous hunting scope and occurrence in a mosaic of savanna and forest in the Gran Sabana, Venezuela to evaluate to what extent the wildlife resource use corresponds to Garden Hunting hypothesis. We applied Royle-Nichols model and binomial regression in order to: 1) assess whether abundance of small and medium wildlife species is higher close to conucos and 2) evaluate whether hunters select hunting localities based on accessibility to wildlife resources (closeness to conuco) more than wildlife abundance.

\section{Results.}


48

We find mixed evidence supporting the Garden Hunting hypothesis predictions. Abundance of small and medium species was high close to conucos but the pattern was not statistically significant for most of them. Pemón seem to hunt in locations dominated by forest, where species abundance was predicted to be higher, than in close vicinity to conucos. Hunting scope focused on the most abundant species located close to the conuco (Cuniculus paca), but also in less abundant and unavailable species (Crax alector, Tapirus terrestrisand Odocoileus virginianus).

\section{Conclusions.}

Our research provided the first attempt of a systematic sampling survey in the Gran Sabana, generating a quantitative dataset that not only describes the current pattern of wildlife abundance, but sets the base-line to monitor temporal and spatial change in highland Amazon. We discuss the applicability of the estimates generated as a baseline as well as, environmental challenges imposed by economic, social and cultural changes such as mining encroachment for wildlife management.

\section{Introduction}

Biodiversity loss has fueled a vigorous debate about sustainability of the current hunting rates in the Neotropics and particularly in the Amazon basin (Robinson \& Bennett, 2004; Lewis, Edwards \& Galbraith, 2015; Ripple et al., 2016; Benítez-López et al., 2017, 2019). Hunting by inhabitants of tropical forests has increased in recent years (Fa, Peres \& Meeuwig, 2002) $\square$ due to human population growth, easier access to undisturbed forests, change in hunting technology, 
71

scarcity of alternative protein sources, and higher demand for bushmeat (Bennett \& Robinson, 2000; Benítez-López et al., 2017) $\square$. Worldwide, more than half of the intact forests and wilderness areas are partially devoid of large mammals and birds, with a significant reduction in abundance (Benítez-López et al., 2017, 2019) $\square \square$. However, current estimates of wildlife abundance reduction do not take into account cultural factors such as taboos, religion, traditional hunting technology, and prey preferences that can have a major influence in patterns of resource use in indigenous communities (Vetter et al., 2011; Carvalho et al., 2015;; Gray, Bozigar \& Bilsborrow, 2015), which have a narrower hunting scope and magnitude compared with nonindigenous hunters (Antunes et al., 2019) $\square$.

Biodiversity patterns in the Amazon have been altered by human societies since preColumbian times (Etter, McAlpine \& Possingham, 2008; Levis et al., 2017) $\square$, but the current rate of transformation and loss are unprecedented and expected to increase in the future (Lewis, Edwards \& Galbraith, 2015; Jędrzejewski et al., 2017; Curtis et al., 2018; Ferrer-Paris et al. 2019) $\square$. Indigenous people in the Neotropics typically create forest-agricultural mosaics based on shifting cultivation systems through clearing of small forest plots or "conucos" by slash-andburn practice (Warner, 1991) $\square$. The Garden Hunting hypothesis (Linares, 1976; NaughtonTreves et al., 2003) $\square$ states that modification of plant community and in situ care of domesticated plants in a shifting cultivation scheme, may generate favorable conditions (e.g. high-nutrient, low-toxicity crops and the abundant browse of regenerating vegetation), for adaptable, fast-reproducing species, such as rodents, peccaries, and armadillos (Constantino, 2019) $\square$, but in turn could act as population sink for large carnivores who are systematically hunted when they venture close to the gardens (Naughton-Treves, 2002) $\square$. Interaction between physical and cultural contexts influences the relationship with wild life species, either as a source 
of protein, pest (Smith, 2005) $\square$ or pets (Naughton-Treves, 2002) $\square \square$. These local effects cascade across the landscape, ultimately shape regional patterns of wildlife abundance and species diversity that might range in effect from mild declines to more severe cases of "empty forests" (Redford, 1992; Naughton-Treves et al., 2003; Smith, 2005; Constantino, 2015; Bogoni, Peres \& Ferraz, 2020) $\square$.

西

1

The Amazon basin still looks like an exceptional large region of intact forest, but in fact, there are large regional differences in biodiversity patterns, cultural diversity and pressures on natural resources (Naughton-Treves, 2002; ter Steege et al., 2020) $\square$. For example, the Guiana Shield or highland Amazon has lower aboveground live biomass (Saatchi et al., 2007) $\square$, anomalous savanna vegetation and forest-savanna mosaic (Rull et al., 2013) $\square$, nutrient deficiency and low water retention capacity in soils than lowland Amazon (Dezzeo et al., 2004) $\square$. Fauna and flora in highland Amazon show high diversity and endemism (Huber, Febres \& Arnal, 2001) $\square$, and lower prevalence of domesticated plants (Levis et al., 2017) $\square$. Low human population density and limited agricultural potential of the lands in highland Amazon, have prevented high rates of land cover change and infrastructure development, and relative lower levels of threats (Rull et al., 2013; Ferrer-Paris et al. 2019) $\square$. While in lowland Amazon the role and magnitude of external factors driving increasing hunting rates have been studied on local and regional scale (Peres, 2000; Zapata-Ríos, Urgilés \& Suárez, 2009; Constantino, 2015; Gray, Bozigar \& Bilsborrow, 2015) $\square$, these patterns remain understudied in the northern, highland Amazon. This is particularly critical since prey abundance or density patterns in this region are poorly known (Hollowell \& Reynolds, 2005; Lim et al., 2005; Stachowicz et al., 2020) $\square$. Indigenous communities in Latin and Central America obtain dietary protein mainly 
118 through fishing and hunting (Bennett \& Robinson, 2000), while shifting cultivation provides

119 them with vegetables, tubers, and some fruits (Rodríguez, 2004; Smith, 2005) $\square$. Both activities,

120 shifting cultivation and hunting raise concerns about the sustainability harvest of natural

121 resources, especially because a transparent, legal framework for hunting is missing all across the

122

123

124

125

126

127

128

129

130

131

132

133

134

135

136

137

138

139

140

Our study focused on Pemón indigenous communities, inhabiting a mosaic of savanna and forest of the Gran Sabana in South Eastern Venezuela, highland Amazon. Extensive agriculture and cattle raising activities are not viable in the Gran Sabana due to the scarcity of nutrients in the soil (Rodríguez, 2004; Rull et al., 2013). Instead, Pemón indigenous communities practice shifting cultivation, fishing and hunting (Coppens \& Perera, 2008) $\square$. They have cultural taboos prohibiting hunting of certain wildlife (e.g. anteaters, foxes, armadillos, sloths, monkeys, and felids such as jaguars and pumas) and preferences for hunting tapirs, deers, peccaries, pacas, turtles and agoutis (Coppens \& Perera, 2008). Additionally, new religion restriction has emerged recently colliding with traditional customs (Knoop et al., 2020) $\square$.

(1)

Here, we combine wildlife occurrence data from the first comprehensive camera-trap survey in the Gran Sabana, and spatially explicit hunting information based on interviews with indigenous communities in order to: 1) describe the Pemón's hunting practice, including scope, occurrence and hunting technology, and 2) evaluate the influence of conucos on animal abundance while controlling for the influence of habitat. Particularly we wanted to test two predictions of the Garden Hunting hypothesis: a) abundance of small and medium wildlife species is higher close to conucos, and b) hunters select hunting localities based on accessibility 
141 to wildlife resource (closeness to conuco) more than wildlife abundance. To test the first

142 prediction, we fitted occupancy models (Royle \& Nichols, 2003) $\square$ to predict relative abundance

143 of medium and small wildlife. For the second prediction, we related localities reported with and

144 without hunting by the interviewees, with variables explaining wildlife abundance and distance

145

146

147

148

149

150

151

152

153

154

155

156

157

158

159

160

161

162

163

164

to nearest conuco. We further compared the predicted abundance of wildlife in hunting and not

hunting sites. This study is intended as a baseline evaluation of wildlife presence under human

activity in a savanna-forest mosaic in highland Amazon. Although, our recommendations are

specific to our case study, our approach to combine different sources of hunting data and species diversity may be widely applied in other regions (Huang et al., 2020) $\square$.

\section{Materials \& Methods}

Study area

\section{列}

The study area covers $615 \mathrm{~km}^{2}$ at the eastern part of the Gran Sabana on the border of the Canaima National Park, with an elevation range $800-1200 \mathrm{~m}$, close to the Venezuela Guyana international border (Fig. 1). Vegetation is dominated by scrub (Clusia spp. and Gongylolepis spp.), broadleaf grassland and savannas of Axonopus spp. with scatter patches of gallery forest (Huber, Febres \& Arnal, 2001) $\square$. The Ilú and Tramén tepuis massif are surrounded by continuous evergreen montane forest. Average temperatures are between 18 and $24^{\circ} \mathrm{C}$ and total annual rainfall is $2000-3000 \mathrm{~mm}$ with a dry season ( $<60 \mathrm{~mm} / \mathrm{month})$ from December to March (Rull et al., 2013). The Pemón are the only indigenous people inhabiting the Gran Sabana. There are four communities within the study area: Kawi (1100 m; - 61.243 W; 5.451 N; 50 people 2016), Mare-Paru (884 m; - 61.184 W; 5.594 N; 45 people in 2016), Uroy-Uaray (1,093 
$165 \mathrm{~m} ;-61.232 \mathrm{~W} ; 5.442 \mathrm{~N} ; 150$ people in 2016) and Wuarapata (896 m; - 61.157; W 5.512 N; 50

166 people in 2016; information about the number of inhabitants was obtained from community

167 leaders or capitanes).

168

169

170

171

172

173

174

175

176

177

178

179

180

181

182

183

184

185

186

187

188

Hunting activity

We used a direct, semi-structured interview approach to get information about hunting and conuco occurrence within the six blocks (see Sampling design and camera trap survey section) (Carvalho et al., 2015) $\square$. We used snowball sampling to identify interview participants. Snowball sampling uses existing study subjects to recruit future subjects from among their acquaintances (Voicu, 2011) $\square$. We initially identified five community leaders known to IS (personal observation). These then contacted and recruited local hunters and farmers, and so on, until we identified 29 people that were willing to be interviewed: three women and 26 men, all > 18 years old. All were indigenous from Wuarapata (11 people), Uroy-Uaray (8), Kawi (5) and Mare-Paru (5) communities. Interviewees represented $10 \%$ of the total population size and were representative in terms of age distribution (mean 44 years old; 22 - 70 years old). The gender unbalance in the sample likely reflects the role of male as spokesperson in their family group (Coppens and Perera 2008).

All communities represented by their authority - capitan - agreed to participate in the research and interview survey, as required by Venezuelan indigenous legislation (La Asamblea Nacional de la Republica Bolivariana de Venezuela, 2005) $\square$. We obtained verbal informed consent from each participant, after explaining research objectives and assuring participants that information would be used only for research and presented in aggregate analyses, protecting each 
207

participant's identity by assigning a numeric code to anonymize participants (Buppert \& McKeehan, 2013) $\square$. There was no compensation for participation. The questionnaire and protocol were approved by Dr. Stanford Zent from the Human Ecology Laboratory of the Venezuelan Institute of Scientific Research (July 2015), who acted as external ethical committee.

An interviewee was considered reliable if a participant could differentiate regional from not-regional animals (e.g. Tremarctos ornatus) shown in pictures and drawings (plates of Linares, 1998) and if the person has been living in the community on the Gran Sabana for most of his/her life. We interviewed each participant independently to minimize biased responses (Jones et al., 2008a) $\square$. We conducted the interviews in Spanish, using a local translator of Arekuna Pemón's dialect when required, and registering the species' local name in Arekuna Pemón's dialect.

\section{our interview survey focused on obtaining baseline information about three aspects of hunting} trip activity: (1) hunting occurrence; (2) hunting scope (which species are most important in term of perceived value and preference); and (3) hunting technologies. We specifically asked about the following topics: (1) whether they currently hunt or not in the vicinity of the conuco and whether they did in the past; (2) the list of hunted species, both mammals and birds; (3) the three most preferred hunted species, being the first species the most preferred; (4) preferred hunting areas; (5) preferred hunting season; (6) occupation (mining, tourism, etc.); (7) food sources (conuco, fishing and hunting, processed food); and (8) hunting technology used on hunting trips. Besides direct questioning, we also evaluated hunting technology by reviewing the pictures from 
212 the camera trap survey (see next section) looking for evidence of hunters, hunters with firearms 213 or dogs. In each sampling unit where the camera trap was installed, we asked whether they hunt

214 (1) or not (0) to obtain spatial distribution of hunting occurrence in the study area. To accurately 215 identify animals hunted, and avoid misinterpretation with animals' local names, we showed

216 217

To identify which species are important game species for Pemón people, we used two criteria: the frequency a given species is reported as target game, and how frequently it is mentioned as preferred game. For that we calculate two indexes for each species, importance of hunting $(H v)$ and hunting preference $(P v)$ (Carvalho et al., 2015) $\square$. Both indexes correct the bias introduced by sampling size in the species citation rate, by multiplying the number of informants giving information on each species. $H v$ is defined as:

Eq. $1 H v=\sum\left(\frac{h}{n}\right) x N$,

where $h$ is the number of times a species is mentioned as a targeted animal, $n$ the total number of citations for all species, and $N$ the number of interviewees

(Carvalho et al., 2015, modified from Phillips et al., 1994; Fernandes-Ferreira et al., 2012) $\square$.

The hunting preference index $(\mathrm{Pv})$, measure the frequency that each species is cited as the first option for hunting among others, and is defined by:

Eq. $2 P v=\sum\left(\frac{p}{n}\right) x N$

where $p$ is the number of times a species is cited as the first option (among the three most preferred hunted species), $n$ the total number of citations for all prey species, and $N$ the number of interviewees. In this case, zero values (i.e. no preference) were excluded. 
Due to the nature of the questions, the $H v$ and $P v$ should be interpreted as the perceived

237 importance and preference. Since we don't have counts of hunted individuals, we cannot

238

239

240

241

242

243

244

245

246

247

248

249

250

251

252

253

254

255

256

257

In some cases, Pemón names do not match scientific names and for example, they use

"savanna deer" or "forest deer" ambiguously for red brocket (Mazama americana) and gray

brocket (Mazama gouazoubira), and "armadillo" for the greater long-nosed armadillo (Dasypus kappleri) and the nine-banded armadillo (Dasypus novemcinctus). So in these cases, the values for $H v$ and $P v$ were calculated at genus level.

\section{Sampling design and camera trap survey}

\section{We used data from a previous camera trap survey conducted between September 2015 -}

April 2016. The original sampling design was developed to optimize covering habitat diversity in order to evaluate how mammal species richness is related to habitat types, and is described in detail in Stachowicz et al. (2020), but we provide here a brief summary of the initial setting and how we adapted data a posteriori for our analysis. Sampling design comprised six $50 \mathrm{~km}^{2}$ blocks within the study area (B01 - B06). Blocks were selected to represent landscapes with different configurations of forest, savanna and shrubs habitats. Since only 30 cameras were available, 
258 sampling was divided into three periods of 60-days each, and in each period a two-levels

259 stratified random sampling was used to select 30 sampling units (five in each block) for camera

260 deployment. This stratification ensures a balanced representation of sampling units with different

261 coverage of habitat types and fragmentation in each block during each period. As a side effect of

262 this, some sampling units with unique values within each block (sites with high tree cover within

263 a block dominated by savanna) were selected for sampling in two or three periods and those

264 cameras were neither relocated nor replaced.

265 deployment and maintenance, with a mean of $16.8 \mathrm{~km}$ walked each day.

Total sampling effort was 4,548 cameras per day, which resulted in 771 detection events for mammals and 226 events for birds across 60 camera sites (Table 1). Events represent sequences of photos separated by less than 5 minutes and showing the same animal species and presumably the same individuals. We identified mammal species (Eisenberg, 1989; Linares, 1998) $\square$ and birds (Hilty, Tudor \& Gwynne, 2003) $\square$ using reference works for Venezuela and South America. We calculated the index of frequency of detection for all mammals and bird species registered with camera traps as the number of detection events for species per 100 days of camera trapping (O’Brien et al., 2010) $\square$ in order to have available information to compare with similar studies in Latin America. 
281

282

283

284

285

286

287

288

289

290

291

292

293

294

295

296

297

298

299

300

301

302

303

Predictive variables: Tree cover, distance to river and distance to conuco

2

3

For this study, we calculated tree cover, distance to nearest conuco and river as covariates of species abundance (Supplementary Material 1). Previous analysis suggested that most mammal species in the study area are more associated with forest habitat than shrubs or savanna (Stachowicz et al. 2020). We used mean tree cover (in percentage) as a quantitative variable correlated with these habitat types and consistent with metrics used for the sampling design. Mean tree cover was calculated from remote sensing products (Hansen MC et al., 2013) $\square$ using a $1 \mathrm{~km}$ buffer around the camera location "tree_buffer." This variable has a bimodal distribution with a lower mode at $10-20 \%$ corresponding with the savanna, a higher mode at $70-80 \%$ corresponding with forest, and intermediate values roughly corresponding with the less common shrub habitat. We used $1 \mathrm{~km}$ radius under the assumption that it is wide enough to represent the area of the most abundant game species home range (lowland paca Cuniculus paca 2 - 3 ha, Jorge, M. \& Peres, 2005; red-rumped agouti Dasyprocta leporina 3.4 - 1.6 ha, Benavides, Arce \& Pacheco, 2017) $\square$ and narrow enough to maintain variability in tree cover within the scale of a camera trapping site (Scotson et al., 2017) $\square$.

7

Presence of rivers is considered an important variable explaining temporal and geographic patterns of distribution and abundance of mammals (Constantino, 2015; Hedwig et al., 2018) $\square$. During the dry season when the camera traps were placed, access to water is an important resource. We calculated distance to nearest rivers (in meters) using vector data of rivers (Señaris, Lew \& Lasso, 2009) $\square$. 
During fieldwork we marked with a GPS the location of active and recently abandoned conucos $(n=25)$ identified in situ, and hunting sites $(n=32)$ reported by interviewees and confirmed by the local guides (Fig. 1). Distance from each camera to the nearest conuco was calculated using the GPS coordinates from cameras and conucos. This variable had an asymmetric distribution with a mean value of $1.58 \mathrm{~km}$ and a range from 0 to $8 \mathrm{~km}$. We also recorded which cameras were located adjacent or near reported hunting sites (binomial variable hunting, FALSE $\mathrm{n}=23$, TRUE $\mathrm{n}=34$ ).

1

2

After visual inspection of the distribution of tree cover, hunting occurrence, and distance to conuco, we decided to discard three cameras with extreme distance values. We also discarded four cameras that were active for less than seven days. Thus all following analyses count on data from 54 cameras within $5 \mathrm{~km}$ of the nearest conuco, with more than seven days of activity (Fig. 2).

\section{Data analysis: Testing Garding Hunting predictions}

(1)

To evaluate the prediction of Garden Hunting Hypothesis we followed a three-step approach using occupancy model, Chi-square test and logistic regression.

2

3

$$
\text { To test the prediction whether abundance of small and medium wildlife species is }
$$

higher close to conucos, we need a measure of influence of conucos while controlling for the influence of habitat on species abundance, and the spatial and temporal heterogeneity in probability of detection. For that, we fit a hierarchical Bernoulli/Poisson $N$-mixture model (Royle 
$\&$ Nichols, 2003) $\square$ for each species to evaluate how the probability of occupancy relates to tree cover and distance to conuco, allowing for abundance-induced heterogeneity in detection probability. These models are a type of latent abundance mixture models, and are often referred as Royle-Nichols models, or RN-models. They are based on the assumption that the detection probability at a survey point $p_{i j}$ depends on the species' site-specific abundance $N_{i}$ : Eq. $4 p_{i j}=1-\left(1-r_{i j}\right)^{N i}$, where $r_{i j}$ is the detection probability of a single individual. Repeated visits at a survey point generate a history of detection/non-detection events $y_{i j}$, from which $p_{i j}$ is estimated. The abundance state $\left(N_{i}\right)$ of site $i$ was modeled as $N_{i} \sim$ Poison $\left(\lambda_{i}\right)$, while the observation process was modeled as $y_{i j} / N_{i} \sim \operatorname{Bernoulli}\left(p_{i j}\right)$. Estimation of $p_{i j}$ allows us to draw conclusions about $N_{i}$. In order to build detection histories for species recorded during the camera trap survey, we considered each camera location as a "site" ( $i ; 54$ in total). We divided the total sampling period of 180 days into several "visits" $(j)$. We tested different values of visit duration and found that a duration of 21 days reduced the prevalence of zeroes but maintained enough number of visits (three for each sampling period, up to nine for cameras fixed in the same location) to successfully fit the model.

Covariates of $N_{i}$ (site covariates) and $p_{i j}$ (observation covariates) were modeled using the logit link. We explored several covariates with alternative parameterizations to ensure best possible model fit given the restricted sample size and low number of detection for some species (see Supplementary Material 1 for details). As site covariates we used tree cover percentage around the camera trap (tree_buffer), distance to river (dist_river), and distance to nearest conuco (dist_conuco), all variables were standardized to zero mean and unit standard deviation. 
350 Since a couple of species might be associated with shrub habitat with intermediate values of tree

351

352

353

354

355

356

357

358

359

360

361

362

363

364

372 cover (Stachowicz et al. 2020) we added a quadratic term (tree_buffer ${ }^{2}$ ) to their models.

We used sampling date, sampling effort (camera/day), and density of direct and indirect off-camera records to account for spatial and temporal heterogeneity in detectability (Cubaynes et al., 2010) $\square$. Sampling date (date) was recorded as the number of days since the start of sampling (21 September 2015) to the beginning of the "visit" and standardized to zero mean and unit standard deviation. Sampling effort (effort) was calculated as the number of days the camera remained active divided by the duration of the visit. Thus, effort was always $\leq 1$, and was set to empty value $(N A)$ when the camera was not present or inoperative during the whole duration of the visit. We calculated tracks density (track_dens) as the inverse distance weighted sum of wildlife activity recorded off-camera (direct observations and indirect evidence such as tracks, scratches, cavities and excrement of animal presence during field-work):

Eq. 4 track_dens $s_{i}=\sum_{j=1}^{k} 1 / d_{i j}^{q}$,

where $d_{i j}$ is the distance between camera $i$ and record $j$ for all $k=159$ records, and $q$ is a fixed power parameter that influences the degree of smoothing in the interpolation, we used $q=0.25$ based on visual inspection. The result was standardized to zero mean and unit standard deviation. $($ date + effort + tracks_dens $))$ and the three site covariates $\left(\lambda\left(\right.\right.$ tree_buffer + tree_buffer $^{2}+$ dist_river + dist_conuco)) using the occuRN function of the R package unmarked (Fiske \& Chandler, 2011) $\square$. We assessed model fit for the full model using goodness of fit test based on Pearson $\chi^{2}$ and parameter bootstrapping with 10,000 samples, and inspecting under- or 
373 overdispersion $\left(\grave{c}\right.$, calculated by dividing the observed $\chi^{2}$ statistic by the mean of the statistics

374 obtained from bootstrap samples), magnitude of parameter estimates and standard errors, and

375 predicted values of the state variable at the sample locations (MacKenzie \& Bailey, 2004; Royle,

376 2006) $\square$. For species with a suitable full model (with $>10$ detections), we proceeded to create a

377 model selection table with all combinations of covariates (32 models for species with linear

378 effect of tree cover and 48 for species with quadratic effect of tree cover), ranked models

379 according to information criteria corrected for small sample size (AICc if $\grave{c} \leq 1$ or QAICc if $\grave{c}>1$ ), 380 and the corresponding $\Delta(\mathrm{Q}) \mathrm{AICc}$ and model weights. calculating the sum of weights of the model containing that variable (Burnham, K.P. \&

384 385 386

We assessed the relative importance of each detection and occupancy covariate by Anderson, 2002; Symonds \& Moussalli, 2011) $\square$. Values range from zero to one indicating increasing levels of support, and we use an informal scale to describe the level of support as very strong $(>0.9)$, strong $(0.6-0.9)$, moderate $(0.3-0.6)$ and low $(<0.3)$. We further calculated model averaged coefficients and predictions of the state variable $(\boldsymbol{\lambda})$ based on the subset of models with $\Delta(\mathrm{Q}) \mathrm{AICc} \leq 10$ (Burnham, Anderson \& Huyvaert, 2011; Mazerolle, 2020) $\square$. In case of overdispersion $(\grave{c}>1)$ we assumed the lack of fit is due to unaccounted sources of error and used the value of $\grave{c}$ to inflate the standard errors and confidence intervals. For underdispersed models ( $\grave{c} \leq 1)$, no modification to standard errors or intervals was made, but consider these as conservative assessments of uncertainty (Kery \& Royle 2015). to wildlife resources we first used the interview responses on vegetation type and season with contingency tables, to evaluate which season and habitat type are used as hunting localities. For 
397 that, we tabulated the number of interview responses from each community for the three levels of 398 preferred hunting vegetation types (forest, savanna and mixed) and the two levels of hunting 399 seasons (dry, and rainy season). We used the $\chi^{2}$ (Chi-square) test to assess the significance of the 400 relationship between variables.

401

Second, we used the data collected during field work at 53 sites with cameras and fitted a

403

404

405

406

407

408

409

410

411

412

413 414

417

418

419
Third, we compared the prediction of latent abundance of the RN-models of each species at these 53 sites, and compared values at sites with and without reported hunting .

\section{Ethical standards}

The study received permits from Ministerio del Poder Popular para Ecosocialismo y Aguas 1419/3/33/2015 and Instituto Nacional de Parques (INPARQUES) 18/16 205, 156, 17 in Venezuela, as well as from the indigenous authorities at each community. The instrument and interview protocols used in Pemón communities were approved and widely used by Fundación la Salle in Venezuela.

\section{Results}

Frequency of detection of mammals and birds 

species were detected once, seven were detected twice and the remaining 29 were detected three

times or more (Table 1, Fig. S1). The most frequently detected (FD) with high number of detections events (D) mammals species were the lowland paca $(\mathrm{FD}=5.38$; $\mathrm{D}=265)$, the redrumped agouti $(\mathrm{FD}=4.2 ; \mathrm{D}=191)$, and the gray brocket $(\mathrm{FD}=1.03 ; \mathrm{D}=47)$. Among birds, the frey-fronted dove (Leptotila rufaxilla) $(\mathrm{FD}=1.05 ; \mathrm{D}=68)$, and the black curassow (Crax alector $)(\mathrm{FD}=1.06 ; \mathrm{D}=48)$ were the most frequently detected (Table 1$)$. The species with the lowest frequency of detection were margay (Leopardus wiedii) $(\mathrm{FD}=0.04 ; \mathrm{D}=2)$, the whitelipped peccary $($ Tayassu pecari $)(\mathrm{FD}=0.04 ; \mathrm{D}=2)$, collared peccary $($ Pecari tajacu $)(\mathrm{FD}=$ 0.04; $\mathrm{D}=2$ ), white-tailed deer (Odocoileus virginianus) $(\mathrm{FD}=0.09 ; \mathrm{D}=4)$, Southern nakedtailed armadillo (Cabassous unicinctus) $(\mathrm{FD}=0.04 ; \mathrm{D}=2)$, common opossum (Didelphis marsupialis $)(\mathrm{FD}=0.04 ; \mathrm{D}=2)$, and capybara (Hydrochoeris hydrochaeris $)(\mathrm{FD}=0.07 ; \mathrm{D}=3)$ (Table 1). During the interviews with Pemón the majority of species registered by camera trap were recognized, except margay and Southern naked-tailed armadillo, while giant armadillo (Priodontes maximus) was only recognized by older interviewees.

Hunting practice: Scope, occurrence, and hunting technology

Of the 29 participants, 19 described themselves as active hunters, five as inactive hunters who hunted in the past and five were no hunters (including the three women interviewed). The most frequent food sources were agriculture (79\%) and fishing and hunting $(65 \%)$, followed by consumption of processed food (51) (multiple choice was permitted). Only $14 \%$ of 
443 interviewees identified hunting as an occupation that they carried out. Among other activities 444 carried out, almost all indicated agriculture (99\%) and a large proportion indicated fishing $445(86 \%)$, mining (37\%), tourism (34\%) and others (27\%): handicrafts, raising of livestock and 446 transport (they could choose more than one activity). The majority of interviewees (79\%), 447 reported that hunted meat was consumed within the family or the community. There was no 448 evidence of commercial hunting - sale of meat, leather or other products derived from the preys.

449

The most frequent hunting technology used during hunting trips was the shotgun (79\%) (Fig. $3 \mathrm{a}$ and $\mathrm{b})$, while traditional bow and arrows (6\%; Fig. 3c), and sling to hunt the birds (10\%; Fig. 3d) have recently gained importance due to limited availability of ammunition, $27 \%$ ). The use of dogs was not reported by interviewees but hunting dogs were visible in three out of nine events of hunters detected by camera traps, where dogs accompanied armed people (Fig. 3a).

According to interviewees, at least nine species of mammals and three species of birds were important game species for Pemón people (Table 2). We detected all of these species with the camera trap survey (see below). The most important species (the highest $H v$ and $\mathrm{P} v$ values; Table

2) were the white-tailed deer, lowland paca, and black curassows. Red-rumped agouti and South American tapir (Tapirus terrestris) were also hunted, but were not mentioned as preferred game (Table 2). Ten percent of interviewees reported that they only hunt and consume deer meat due to religion restrictions. 
We explored latent abundance mixture model for 25 mammals and four bird species but 467 discarded models for species with poor fit (Supplementary Material 1 and 2). We completed

model selection and averaging for 12 mammal and three bird species with more than ten detections and reasonably good fitting models. Among these 15 species, only ocelot (Leopardus pardalis) $(\grave{c}=1.77)$ and nine-banded armadillo $(\grave{c}=1.29)$ showed sign of overdispersion (Table 3$)$, most species showed under-dispersion, with most values between 0.3 and 0.9 except the low value for Great Tinamu (Tinamus major) $(\grave{c}=0.21)$.

All variables received some degree of support for all species $(\Sigma(\mathrm{Q}) \mathrm{AICw}>0.23$; Table 3$)$. Among the covariates of probability of detection, sampling effort had the highest level of support in most species (six species with strong or very strong support, Table 3), except for $D$. imperfecta (track density received most support), nine-banded armadillo (date), while three species had similar low values for all three covariates (jaguar (Panthera onca), ocelot and great tinamu; Table 3).

Among the covariates of lambda, tree cover had strong to very strong support for most of the species except ocelot (moderate), giant anteater (Myrmecophaga tridactyla) (moderate) and lowland paca (low). For most species tree cover was modelled as a linear variable, except for grey-fronted dove and tayra (Eira barbara). Distance to conucos had only strong support for tayra, lowland paca and black curassow, moderate support for two species and low support for the rest (Table 3). While the distance to the river variable had high values for giant anteater and jaguar, and low for the rest of the species. 
Conditional model averages of the coefficient of distance to conuco was negative for most species (higher estimates of latent abundance near to conucos) and close to zero or positive for Guianan white-eared opossum (Didelphis imperfecta), great tinamou, crab-eating fox (Cerdocyon thous), and black curassow (Fig. 4). However, the 95\% confidence intervals of the estimates overlap with zero, except for lowland paca, tayra, and black curassow.

In general, and despite few outliers, abundance predictions from the mixture models were higher for most species in sites where the Pemón reported hunting activity (Fig. 5). This was true for species with different values of hunting preference $(H v)$ and for species not mentioned as important prey for Pemón, including carnivores (with the exception of crab-eating fox; Fig. 5).

\section{Selection of hunting localities}

Hunting occurrence in the study area was detected up to $5 \mathrm{~km}$ distance from conucos, both in the savanna and forest (Fig. 2, Supplementary Material 1). Sampling units with reported hunting activity were mostly located at $2.5 \mathrm{~km}$ from nearest conucos with tree cover $>40 \%$ (Fig. 2). Tree cover $(p=0.006)$ and distance to rivers $(p=0.070)$ had a positive significant effect on the hunting occurrence, but the effect of distance to conuco $(p=0.202)$ was negative and not significant (Table 4).

$$
\text { savanna (31\%), and mixed forest - savanna areas (34\%). This pattern was similar across }
$$
communities $\left(\chi^{2}=7.67\right.$; degree freedom $=6 ; p \leq 0.263$; Table 5). The majority of interviewees hunt during the rainy season (68\%), between May and August, while only $21 \%$ interviewees hunt 
513 all year round, and $11 \%$ had not a preferred season to hunt. This pattern was similar across

514 communities $\left(\chi^{2}=9.89 ;\right.$ degree freedom $\left.=6 ; p \leq 0.129\right)($ Table 5$)$.

515

516

517

518

519

520

521

522

523

524

525

526

527

528

529

530

531

532

533

534

\section{Discussion}

A clear understanding of the relationship between human activities and wildlife abundance patterns is crucial to identify the most appropriate conservation interventions in complex landscapes with high biological and cultural diversity (Weinbaum et al., 2013; Gavin et al., 2015) $\square$. For the Gran Sabana and the Canaima National Park, despite their importance as UNESCO World Heritage Site and the longstanding presence of Pemón people, base-line knowledge about wildlife abundance patterns and how it changes across time, space, and as response to human-based stressors is limited. Our research goes a step forward to fulfill these gaps by providing the first attempt of a systematic sampling survey in the Gran Sabana, generating a quantitative dataset that not only describes the current pattern of wildlife abundance, but sets the base-line to monitor temporal and spatial changes. Further, to our knowledge, this study is the first in providing quantitative and updated information about Pemón's hunting occurrence, scope and practice, which has been poorly described across the highland Amazon region. Last, but not less important, our hypothesis-based approach allowed us to go beyond a list of species present and hunted, to try to shed light upon underlying patterns that can be better integrated in programs for sustainable use of wildlife in accordance with the cultural and social context. Finally, we place our research in the current social and economic situation of mining encroachment in Guyana Shield. 
535

536

537

538

539

540

541

542

543

544

545

546

547

548

549

550

551

552

553

554

555

556

557

\section{Current pattern of wildlife abundance}

The vegetation type had the most significant role explaining the abundance pattern of both herbivores and carnivorous species in the study area (Table 3; Stachowicz et al., 2020). Most species modeled, except the crab-eating fox, were more abundant in areas with higher cover trees, which may correspond with forest and shrublands (Table 3). In the Gran Sabana, in contrast to other Amazon areas, the savanna ecosystem is more prevalent than forest (Rull et al. 2013) thus, the observed higher abundance in forest and shrublands may reflect the patchy distribution of resources (water, shelter and food) in the study area. Although hydric resources had low importance for most modelled species, their inclusion significantly improved RoyleNichols model performance. In general, neotropical mammals shown higher richness in areas close to water (Di Bitetti et al., 2008; Ferreguetti, Tomas \& Bergallo, 2017) $\square$. For example, rivers and streams were important to explain abundance pattern for the jaguar (Table 3; Cullen et al., 2013), that used to find their preys close to rivers (Weckel, Giuliano \& Silver, 2006) $\square$. Also, for the giant anteater, gallery forests along river banks, provides refuge or escape routes from fires (Diniz \& Brito, 2013) $\square$.

As expected, the medium and small species, with fast growing rates like the lowland paca and the red-rumped agouti, had the highest frequency of detection (Table 1). The gray brocket, although less frequent, was yet a prevalent species in the area, which contrast with the almost absence of other deer species, the white-tailed deer (Table 1). Formerly widely distributed and abundant, the white-tailed deer was only detected four times across the six survey months (Table 1). This low detection rate was unexpected because this species has a higher tolerance and 
558 adaptation capacity to different habitats, than other ungulates such as peccaries and tapirs, being 559 detected even near human population centers (Gallina \& Lopez Arevalo, 2016) $\square$. Also, Pemón 560 refers that 10 years ago, the white-tailed deer used to be more abundant in the area (information 561 provided by interviewees). Although currently classified as Least Concern in the national

562

Evidence supporting the Garden Hunting prediction about higher abundance of small and medium wildlife species close to conucos was not conclusive: Although most of the herbivorous species modeled seem to have higher abundance close to conucos (Fig. 4) this effect was not significant, and the only two species significantly attracted by conucos were tayra and lowland paca. This pattern seems to agree with previous results on which tayra does not show a marked preference for any type of habitat, while lowland paca showed significant preference to shrublands or intermediate habitat, which likely correspond to conuco (Stachowicz, et al., 2020).

Among the species not attracted by conucos, black curassow was the only showing a significant effect (Fig. 4), which contrasts with previous evidence in lowland Amazon and Piaroa communities where cracids were observed within conucos in high abundance (Zent, 1997) $\square$. These difference might be due to different relationship between indigenous communities and 
581 this bird species (with Piaroa using this species as a pet, while for Pemon is a game species), or 582 different habitat preferences of the species between lowland and highland Amazon. For other 583 species of curassow, the Endangered red-billed curassow (Crax blumenbachii), in Brazil was 584 more persistent in forest patches faraway from settlements, with hunting pressure potentially

585 586 587 588 589

590

597 598 599 600 601 602 603 exerting more influence on population persistence than habitat quality (Rios et al., 2020). Again, more detailed population studies are required to better describe population status of this and other endangered species in Gran Sabana, as well as improve our understanding of landscape transformation and human activities in their population dynamics (BirdLife International, 2016).

\section{Pemón's hunting occurrence and practice}

We did not find support for the predictions of higher occurrence of hunting close to conucos (Table 4). Pemón seem to hunt in locations dominated by forest (Table 4 and 5), where species abundance was predicted to be higher (Fig. 5), than in close vicinity of conucos. To our knowledge, there are no studies describing the size of Pemón hunting territories. Here, we found that hunting activity was mostly focused on a radius of $2.5 \mathrm{~km}$ from conuco, but we have limited data to test long range hunting ( $>5 \mathrm{~km}$ ) (Fig. 2). Evidence from other Pemón community, Tuauken located at $\sim 30 \mathrm{~km}$ from study area, describes three types of hunting trips (Urbina, 1979) $\square:$ 1) hunting of large mammals such as tapirs and deer, implemented in a planned manner by teams of many people, 2) hunting of smaller animals such as paca or aguti, implemented in a semi-planned way by small teams and even by a single person, and 3) the informal, unplanned hunts of turkeys and birds. The hunting detected in our research likely corresponds with the second and third hunting types: small mammals and birds hunted in hunting trips performed within short to medium distance from conuco. 
Traps, incidental capture of game, and even the use of fire to capture deer and other large

606

607

608

609

610

611

612

613

614

615

prey species have been previously reported as hunting methods in Pemón communities (Bilbao, Leal \& Méndez, 2010; Sletto \& Rodriguez, 2013) $\square$. However, during the 120 days of field work, we did not detect traps, supporting the notion that traps are infrequently used by South American indigenous communities (Dunn \& Smith, 2011) $\square$. The use of dogs was registered on camera traps but not mentioned by hunters during the interview. Literature indicates the presence of dogs in hunting zones adjacent to the community, but hunters reported to kills the prey with a firearm, not a dog (Dunn and Smith 2011). We compiled anecdotal information about incidental hunting, mostly pigeons (grey-fronted dove), which were abundant in the study area (Table 1; Fig 5). However, this activity was not even considered as hunting, diminishing it as part of kids games and training (IS personal observation).

Hunting scope focused on the most abundant and easily accessible species, the lowland paca, which was the most important hunting prey for Pemón people (Table 2). In lowland Venezuelan Amazon, hunting scope of Ye'kwana and Sanema indigenous appears to be similar to those observed by Pemón communities in this study: they hunt the most abundant mammals in the area (the white-lipped peccary and the lowland paca; Castellanos, 2001; Ferrer et al., 2013) $\square$. In a broader geographical context, this focus on high abundant and accessible species (usually pacas, deers and peccaries) was also reported in indigenous communities in Panama (Smith, 2005) $\square$, Honduras (Dunn \& Smith, 2011) $\square$, in the Peruvian Amazon (Francesconi et al., 2018) $\square$, French Guiana (Richard-Hansen et al., 2019) $\square$ and in Guiana (Roopsind et al., 2017) $\square$.

The fact that other less abundant or accessible species like the white-tailed deer and the black curassow were identified as important prey for the Pemón, suggest that they practiced 
627 selective hunting (Table 2). For the lowland paca with a high reproduction rate and short 628 gestation period (Grzimek, 2003a) $\square$, this selective hunting may not translate into abundance 629 reduction. Indeed, this species has been considered as manioc and maize crop pest in Western 630 Brazilian Amazonia and Honduras (Abrahams, Peres \& Costa, 2018) $\square$. Nevertheless, in

Ecuadorian Amazon, abundance of lowland pacas, red brockets and collared peccaries have been substantially reduced within a $3 \mathrm{~km}$ radius of the communities (Zapata-Ríos, Urgilés \& Suárez, 2009) $\square$ and $2 \mathrm{~km}$ in western Panama (Smith, 2008) $\square$, raising concern about sustainability of hunting. For the white-tailed deer, with lower reproductive rate and longer gestation period (Grzimek, 2003b) $\square$, this pressure likely had reduced their abundance: frequently hunted in the last decade as source of animal protein and sport hunting (Danields, 1991; Gallina \& Lopez Arevalo, 2016) $\square$, currently was scarcely reported as hunted. Our current dataset does not allow us to discriminate whether the apparent reduction in abundance of the white-tailed deer is driven by overhunting, demography, environmental or genetics factors (Madhusudan \& Karanth, 2002; Grzimek, 2003b) $\square$. A sampling design surveying both locations with and without deer hunting across different seasons, and taking into account spatial distribution of potential stressors, will help understand the relative importance of hunting and other factors into deer abundance.

Interestingly, we did not detect reports of human - carnivore conflicts, even though ocelot and tayra were detected close to conucos (Fig 4). Abundance of ocelot and jaguar were predicted to be higher in Pemón's hunting locations (Fig. 5) suggesting potential competition for prey resources between carnivorous and human. Our failure to find evidence of carnivore poaching or conflict in Pemón communities may be a real pattern and not under-reporting because: 1) in the Pemón communities people openly report hunting for other threatened species such black curassows, 2) in other regions of Venezuela (even very close like Imataca), when a 
650 poaching or conflict event exists, people freely exhibit felids skins at their houses as trophy hunts 651 and talk about the chasing of conflicting animals (IS personal observation), and 3) the cultural 652 taboo in Pemón people regarding hunting of carnivores (Coppens \& Perera, 2008) seems to be 653 reinforced by more recently adopted religious which restrict the hunting scope only to deers 654 (Bonet, 2020; Knoop et al., 2020) $\square$. However, under-reporting is still expected because of poor 655 recall capacity of interviewees. Clearly this topic requires a more in depth research, using 656 specialized questioning techniques widely applied to assess illegal wildlife trade and support 657 sensitive data collection (Nuno \& St. John, 2014) $\square$.

The Garden Hunting hypothesis: current pattern of natural resource use

Our results suggest that social-cultural context, and not only the surrounding environment, determine where and what is hunted. Species attracted by the 'garden' such as lowland pacas, red-rumped agouties and South American tapirs, were accessible and preferred prey (Fig. 4). In contrast, other species similarly attracted to conucos such as the long-nosed armadillo and the grey-fronted dove, were not preferred as hunting game (Table 2). This result contrasts with the general notion that garden farmers often rely on game hunted in swidden gardens as a key source of protein (Naughton-Treves, 2002) $\square$, but agrees with more nuanced studies evaluating the use and perception of wildlife in local communities in Peru, where $51 \%$ of interviewee considered that the wildlife attracted to swiddens gardens bring no benefits for them (Naughton-Treves, 2002).

Pemón people traditionally had a very diffusely distributed population (Coppens \& Perera, 2008) $\square$, with small and low densely populated settlements around which conucos were cut in mature forest fragments adjacent to open savanna. In the last 30 years, Pemón 
672 communities have become more permanent and bigger (Rull et al., 2013), resulting in a more 673 intensive land use (shorter than 5-26 years fallow periods that allows forest recovery; Kingsbury, 674 2001), and changes in the conuco locations. Again, there is no evidence of how settlement size 675 could affect hunting practices in Pemón communities. Several authors discuss how settlement

676

677 678 679 680 681 682 683 684 685 686 687

nucleation and sedentism around missions, along highways or tourist attractions has led to localized game depletion in the Gran Sabana (Huber \& Zent, 1985) $\square$, but without supporting data. Studies from other indigenous communities, the Piaroa, an indigenous group inhabiting in the forested mountains of the Middle Orinoco, that were living in small, scattered, and highly mobile communities until recently (Mansutti, 1990; Zent, 1992) $\square$, suggest that increase in the hunting size territory is not proportional to the increase in the population size (Freire, 2007) $\square$. However, Piaroa territories are bigger than those surveyed in the present study, and a study covering a bigger area and more communities is necessary to evaluate the effect of settlement size in hunting practices.

In general, Pemón practice seems to be sustainable but the perceived reduction in abundance of important game species raises concerns for both livelihood sustainability and biodiversity conservation. The general low impact of the current hunting pattern in the Gran Sabana could be explained by their particular economic and cultural context. In the last decade frequency and amount of hunting has been limited because of the high prices of cartridges. The lack of ammunition forced the adoption of traditional, less effective hunting techniques such as bow arrows and sling, which only allow hunting for small prey and birds (Fig. 3c, d). As a result, hunting has become more incidental, carried out only in special festivities. However, even with cartridges, Pemón people seem to have relied more on conucos' production and fishing as sources of protein, while hunting was a secondary source of protein (Urbina, 1979) $\square$. 


8

Additionally, protestant missionaries that have been present for more than a decade in the study area, encourage indigenous communities to vegetarianism and quit hunting.

The new concern regards to creation of a large scale $\left(12000 \mathrm{~km}^{2}\right)$ and extensive mining development plan the Orinoco Mining Arc in 2016 (OMA; Lozada, 2019) $\square$ in South of Venezuela, which might change the current pattern of managing natural resources in the Gran Sabana. It stands in non-compliance of environmental and indigenous social rights, increasing the risk of pollution, and social and political conflict (Giordano et al., 2018) $\square$ which likely could increase demand for natural resources, including deforestation and over-hunting (Rodríguez, 2000) $\square$. Already, in one of the studied communities, Uroy - Uaray, Pemón people have extracted poor quality gold until 2012, and currently young men are leaving the community to work in legal and illegal mines inside and outside of the Canaima National Park (SOS-Orinoco, 2018) $\square$.

\section{Study limitations}

Carrying out field works in conflict zones such as Venezuela (Bull, 2020) $\square$, requires overcoming logistical challenges such as limitation of food and gasoline supply, distrust from local communities, and constant presence of army and paramilitary, altogether impacting safety of researchers and jeopardizing the time and geographical extent of the surveys (Gaynor et al., 2016) $\square$. This challenging social context, combined with budget limitations resulted in short sampling effort, which was limited to six months in the dry season and limited number of cameras. This likely impacted the statistical power of the analysis and limited our ability to 
717 detect significant effects (Kery \& Royle 2015). Although with this effort we were able to detect $71882 \%$ of expected mammals species in the study area (Huber, Febres \& Arnal, 2001; Stachowicz 719 et al., 2020), we failed to capture seasonal variations in abundance and occurrence of herbivores 720 and carnivores. For example, collared peccary and white-lipped peccary, were poorly detected 721 during the survey, likely because they perform seasonal movements during the dry season 722 (Keuroghlian, Eaton \& Longland, 2004) $\square$.

Although our sampling design optimized spatial coverage, we did not have enough records (37\% of species) to fit all species occupancy models. We found an important effect of sampling effort on detectability of species (Table 3), but date of sampling was important only for a few species. Pemón reported that the rainy season was their prefered season for hunting (Table 3), but our sampling survey covered only the dry season, thus we cannot compare how wildlife abundance patterns change across the year (Ahumada, Hurtado \& Lizcano, 2013) $\square$. Increasing sampling effort in both temporal and spatial scale, would allow us to get a better picture of their dynamics and variability.

Although our interview sampling size was low, it represented $10 \%$ of the total population size and was representative in terms of age distribution. However, low participation in interviews among indigenous groups in Amazon is frequently reported (Knoop et al., 2020). In any case, we are confident that concealment of hunting scope was low: People openly share hunting reports for both threatened and not threatened species. This low level of concealment is likely related to missing law enforcement protocols or tools to evaluate trends and magnitude of wildlife use. 
We were able to obtain spatial information of hunting activity in the study area, but a

739

740

longer presence of at least one year in the study area might assure higher interview success.

Extended survey time, combined with daily interviews approached, likely will result in a more accurate and detailed description of hunting patterns (Jones et al., 2008b) $\square$, including quantities of prey and frequency of hunting.

\section{Conclusions}

Large scale analysis of hunting rates might overlook the factors operating locally, such as landscape type and matrix, wildlife diversity, cultural hunting taboos, religion, type of protein sources (fishing, hunting), hunting technology, economic context or emerging threats, leading to misinterpretations and incorrect management decisions. Understanding the relationship between human activities and wildlife diversity patterns is crucial to identify the most appropriate conservation interventions in complex landscapes with high biological and cultural diversity (Weinbaum et al., 2013; Gavin et al., 2015; Rovero et al., 2020) $\square$.

Our study provides a baseline to evaluate the impact of the growing and accelerated threats in the Gran Sabana ecosystem of highland Amazon. On one hand, the current level of shifting cultivation practices seems to be sustainable and gives a room for sustainable agricultural production in the long term. On the other, cultural transformations, migration of non-indigenous groups for mining activity may possibly generate higher hunting activity. Update of the obsolete legal framework and increased capacity for law enforcement regulating wildlife use will be necessary to avoid local depletion of threatened and preferred prey species. Cost-efficient monitoring strategies will be required to assess the effectiveness of the proposed conservation actions. At regional scale, abundance of functional groups (Vetter et al., 2011; Mason \& 
760 Mouillot, 2013; Rovero et al., 2020) $\square$ may be used as an indicator of ecosystem functionality

761 (Ferrer-Paris et al. 2019). While, at the local scale the occurrence estimates provided by this and

762 similar studies (Stachowicz et al., 2020) can be used to calculate maximum sustainable offtake

763 quantitatively combine the supply and demand for wildlife resources (Robinson \& Bennett, $7642004) \square$.

765

766 Acknowledgments

767

768

769

770

771

772

773

774

775

776

777

778

779

780

We especially thank the Pemón communities Kawi, Uroy-Uaray and Wuarapata in the

Gran Sabana for supporting this project. Especially thanks to Nigel Noriega for language editing.

\section{References}

Abrahams MI, Peres CA, Costa HCM. 2018. Manioc losses by terrestrial vertebrates in western Brazilian Amazonia. Journal of Wildlife Management 82:734-746. DOI: 10.1002/jwmg.21443.

Ahumada JA, Hurtado J, Lizcano D. 2013. Monitoring the Status and Trends of Tropical Forest Terrestrial Vertebrate Communities from Camera Trap Data: A Tool for Conservation. PLoS ONE 8. DOI: 10.1371/journal.pone.0073707.

Antunes AP, Rebêlo GH, Pezzuti JCB, Vieira MAR de M, Constantino P de AL, Campos-Silva JV, Fonseca R, Durigan CC, Ramos RM, Amaral JV do, Camps Pimenta N, Ranzi TJD, Lima NAS, Shepard GH. 2019. A conspiracy of silence: Subsistence hunting rights in the Brazilian Amazon. Land Use Policy 84:1-11. DOI: 10.1016/j.landusepol.2019.02.045. 
781

782

783

784

785

786

787

788

789

790

791

792

793

794

795

796

797

798

799

800

801

802

Benavides C, Arce A, Pacheco LF. 2017. Home range and habitat use by pacas in a montane tropical forest in Bolivia. 47:227-236. DOI: 10.1590/1809-4392201603163.

Benítez-López A, Alkemade R, Schipper AM, Ingram DJ, Verweij PA, Eikelboom JAJ, Huijbregts MAJ. 2017. The impact of hunting on tropical mammal and bird populations. Science 356:180-183. DOI: 10.1126/science.aaj1891

Benítez-López A, Santini L, Schipper AM, Busana M, Huijbregts MAJ. 2019. Intact but empty forests? Patterns of hunting induced mammal defaunation in the tropics. PLoS Biology 17:1-18. DOI: 10.1371/journal.pbio.3000247.

Bennett EL, Robinson JG. 2000. Carrying capacity limits to sustainable hunting in tropical forests. In: Hunting for sustainability in tropical forests, 13-30. 13-30. DOI

Bilbao BA, Leal A V., Méndez CL. 2010. Indigenous Use of Fire and Forest Loss in Canaima National Park, Venezuela. Assessment of and Tools for Alternative Strategies of Fire Management in Pemón Indigenous Lands. Human Ecology 38:663-673. DOI: $10.1007 / \mathrm{s} 10745-010-9344-0$.

BirdLife International. 2016. Crax alector. The IUCN Red List of Threatened Species 2016: e.T22678534A92777326.

Di Bitetti MS, Paviolo A, Ferrari CA, De Angelo C, Di Blanco Y. 2008. Differential responses to hunting in two sympatric species of brocket deer (Mazama americana and M. nana). Biotropica 40:636-645. DOI: 10.1111/j.1744-7429.2008.00413.x.

Bogoni JA, Peres CA, Ferraz KMPMB. 2020. Extent, intensity and drivers of mammal defaunation: a continental-scale analysis across the Neotropics. Scientific Reports 10:1-16. DOI: $10.1038 / \mathrm{s} 41598-020-72010-w$. 
Bonet NG. 2020. Mining against the State? Gold Mining and Emerging Notions of Territoriality in Southeastern Venezuela. Bulletin of Latin American Research:1-14. DOI: 10.1111/blar.13020.

Bull B. 2020. The crisis in Venezuela Author ( s ): Benedicte Bull and Antulio Rosales Source: European Review of Latin American and Caribbean Studies / Revista Europea de Estudios Latinoamericanos y del Caribe, January-June 2020 , No . 109 (January-June Published b. 109:1-20. DOI: 10.32992/erlacs.10587

Buppert T, McKeehan A. 2013. Guidelines for applying free, prior and informed consent: A Manual for Conservation International. Arlington, VA.

Burnham, K.P., Anderson DR. 2002. Model selection and multimodal inference, a practical information-theoretic approach. New York: Springer-Verlag.

Burnham KP, Anderson DR, Huyvaert KP. 2011. AIC model selection and multimodel inference in behavioral ecology: Some background, observations, and comparisons. Behavioral Ecology and Sociobiology. DOI: 10.1007/s00265-010-1029-6.

Carvalho M, Palmeirim JM, Rego FC, Sole N, Santana A, Fa JE. 2015. What motivates hunters to target exotic or endemic species on the island of São Tomé, Gulf of Guinea? Oryx 49:278-286. DOI: 10.1017/S0030605313000550.

Castellanos HG. 2001. La cacería de subsistencia en bosques húmedos del neotrópico sudamericano: un análisis y perspectiva regional. Boletín de Antropología, Universidad de Antioquia2 15:73-87.

Constantino PAL. 2015. Dynamics of hunting territories and prey distribution in Amazonian Indigenous Lands. Applied Geography 56:222-231. DOI: 10.1016/j.apgeog.2014.11.015. 
825 Constantino P de AL. 2019. Subsistence Hunting with Mixed-Breed Dogs Reduces Hunting

826 Pressure on Sensitive Amazonian Game Species in Protected Areas. Environmental Conservation 46:92-98. DOI: 10.1017/S0376892918000322.

828

829

830

Coppens MV, Perera MA. 2008. Los Aborigenes de Venezuela. Caracas: Fundación La Salle de Ciencias Naturales; Instituto Caribe de Antropología y Sociología; Monte Ávila Editores Latinoamericana.

Cubaynes S, Pradel R, Choquet R, Duchamp C, Gaillard JM, Lebreton JD, Marboutin E, Miquel C, Reboulet AM, Poillot C, Taberlet P, Gimenez O. 2010. Importancia de considerar la heterogeneidad de detección al estimar la abundancia: El caso de lobos franceses. Conservation Biology 24:621-626. DOI: 10.1111/j.1523-1739.2009.01431.x.

Cullen L, Sana DA, Lima F, de Abreu KC, Uezu A. 2013. Selection of habitat by the jaguar, Panthera onca (Carnivora: Felidae), in the upper Paraná River, Brazil. Zoologia 30:379387. DOI: $10.1590 / \mathrm{S} 1984-46702013000400003$.

Curtis PG, Slay CM, Harris NL, Tyukavina A, Hansen MC. 2018. Classifying drivers of global forest loss. Science 361:1108-1111. DOI: 10.1126/science.aau3445.

Danields H. 1991. Biología y habitat del venado caramerudo." El venado en Venezuela: conservación, manejo, aspectos biológicos y legales.

Dezzeo N, Chacón N, Sanoja E, Picón G. 2004. Changes in soil properties and vegetation characteristics along a forest-savanna gradient in southern Venezuela. Forest Ecology and Management 200:183-193. 
845

846

847

848

849

850

851

852

853

854

855

856

857

858

859

860

861

862

863

864

865

Diniz MF, Brito D. 2013. Threats to and viability of the giant anteater, Myrmecophaga tridactyla (Pilosa: Myrmecophagidae), in a protected cerrado remnant encroached by urban expansion in central Brazil. Zoologia 30:151-156. DOI: 10.1590/S1984-46702013000200005.

Dunn MA, Smith DA. 2011. The spatial patterns of miskitu hunting in northeastern Honduras: Lessons for wildlife management in tropical forests. Journal of Latin American Geography 10:85-108. DOI: 10.1353/lag.2011.0020.

Eisenberg JF. 1989. Mammals of the neotropics: the northern Neotropics. vol. 1.

Etter A, McAlpine C, Possingham H. 2008. Historical patterns and drivers of landscape change in Colombia since 1500: A regionalized spatial approach. Annals of the Association of American Geographers 98:2-23. DOI: 10.1080/00045600701733911.

Fa JE, Peres CA, Meeuwig J. 2002. Bushmeat Exploitation in Tropical Forests: an Intercontinental Comparison. Conservation Biology 16:232-237. DOI: 10.1046/j.15231739.2002.00275.x.

Fernandes-Ferreira H, Mendonça SV, Albano C, Ferreira FS, Alves RRN. 2012. Hunting, use and conservation of birds in Northeast Brazil. Biodiversity and Conservation 21:221-244. DOI: 10.1007/s10531-011-0179-9.

Ferreguetti AC, Tomas WM, Bergallo HG. 2017. Differences in the mammalian habitat use in a mosaic of vegetation types of an Atlantic rain-forest reserve, Brazil. Mastozoología neotropical 24:355-364.

Ferrer-Paris JR, Zager I, Keith DA, Oliveira-Miranda MA, Rodríguez JP, Josse C, González-Gil M, Miller RM, Zambrana-Torrelio C, Barrow E. 2019. An ecosystem risk assessment of 
temperate and tropical forests of the Americas with an outlook on future conservation strategies. Conservation Letters 12:e12623. DOI: 10.1111/conl.12623.

Ferrer A, Lew D, Vispo C, Felix D. 2013. Uso de la fauna silvestre y acuática por comunidades del bajo río Caura (Guayana venezolana). Biota Colombiana 14:33-44. DOI: 10.21068/bc.v14i1.274.

Fiske IJ, Chandler RB. 2011. Unmarked: An R package for fitting hierarchical models of wildlife occurrence and abundance. Journal of Statistical Software 43:1-23. DOI: 10.18637/jss.v043.i10.

Francesconi W, Bax V, Blundo-canto G, Willcock S, Cuadros S, Vanegas M, Quintero M, Torres-vitolas CA. 2018. Hunters and hunting across indigenous and colonist communities at the forest- agriculture interface: an ethnozoological study from the Peruvian Amazon. Jornal of Ethnobiology and Ethnomedicine 14:1-11. DOI: 10.1186/s13002-018-0247-2

Freire GN. 2007. Indigenous shifting cultivation and the new Amazonia: A Piaroa example of economic articulation. Human Ecology 35:681-696. DOI: 10.1007/s10745-007-9120-y.

Gallina S, Lopez Arevalo H. 2016. Odocoileus virginianus. The IUCN Red List of Threatened Species 2016: e.T42394A22162580Title https://dx.

Gavin MC, McCarter J, Mead A, Berkes F, Stepp JR, Peterson D, Tang R. 2015. Defining biocultural approaches to conservation. Trends in Ecology and Evolution 30:140-145. DOI: 10.1016/j.tree.2014.12.005.

Gaynor KM, Fiorella KJ, Gregory GH, Kurz DJ, Seto KL, Withey LS, Brashares JS. 2016. War and wildlife: linking armed conflict to conservation. Frontiers in Ecology and the Environment 14:533-542. DOI: 10.1002/fee.1433. 
888 Giordano AG, Moran V, Noriega N, Ferrer-Paris JR, Stachowicz I, Kreft S, Melissa V. 2018.

889

890

891

892

893

894

895

896

897

898

899

900

901

902

903

904

905

906

907

908

909

ORINOCO MINING ARC POLICY STATEMENT. In: Conference Statement for the

Orinoco Mining Arc . Latin America and Caribbean Congress for Conservation Biology (LACCCB 2018) in Trinidad and Tobago.

Gray CL, Bozigar M, Bilsborrow RE. 2015. Declining use of wild resources by indigenous peoples of the Ecuadorian Amazon. Biological Conservation 182:270-277. DOI: 10.1016/j.biocon.2014.12.022.

Grzimek B. 2003a. Grzimek’s Animal Life Encyclopedia Vol 16. Farmington Hills, MI: Gale Group.

Grzimek B. 2003b. Grzimek's Animal Life Encyclopedia Vol 15. Farmington Hills, MI: Gale Group.

Hansen MC, Potapov PV, Moore R, Hancher M, Turubanova SA, Tyukavina A, Thau D, Stehman SV, Goetz SJ, Loveland TR, Kommareddy A. 2013. High-resolution global maps of 21 st-century forest cover change. Science 342:850-853. DOI: 10.1126/science.1244693

Hedwig D, Kienast I, Bonnet M, Curran BK, Courage A, Boesch C, Kühl HS, King T. 2018. A camera trap assessment of the forest mammal community within the transitional savannahforest mosaic of the Batéké Plateau National Park, Gabon. African Journal of Ecology 56:777-790. DOI: 10.1111/aje.12497.

Hilty SL, Tudor G, Gwynne JA. 2003. Birds of Venezuela. New Jersey: Princeton University Press.

Hollowell T, Reynolds RP. 2005. Checklist of the Terrestrial Vertebrates of the Guiana Shield. Bulletin of the Biological Society of Washington.

Peer) reviewing PDF | (2020:07:51031:2:1:NEW 20 May 2021) 
910 Huang G, Sreekar R, Velho N, Corlett RT, Quan RC, Tomlinson KW. 2020. Combining

911 camera-trap surveys and hunter interviews to determine the status of mammals in protected

912 rainforests and rubber plantations of Menglun, Xishuangbanna, SW China. Animal

913 Conservation 23:689-699. DOI: 10.1111/acv.12588

914

915

916

917

918

Huber O, Febres G, Arnal H. 2001. Ecological Guide to the Gran Sabana. Canaima National Park, Venezuela. Caracas, Venezuela: The Nature Conservancy.

Huber O, Zent S. 1985. Indigenous people and vegetation in the Venezuelan Guayana: Some ecological considerations. SCIENTIA GUAIAN EE:37-64.

Jędrzejewski W, Boede EO, Abarca M, Sánchez-Mercado A, Ferrer-Paris JR, Lampo M, Velásquez G, Carreño R, Viloria ÁL, Hoogesteijn R, Robinson HS, Stachowicz I, Cerda H, Weisz M del M, Barros TR, Rivas GA, Borges G, Molinari J, Lew D, Takiff H, Schmidt K. 2017. Predicting carnivore distribution and extirpation rate based on human impacts and productivity factors; assessment of the state of jaguar (Panthera onca) in Venezuela. Biological Conservation 206:132-142. DOI: 10.1016/j.biocon.2016.09.027.

Jones JPG, Andriamarovololona MM, Hockley N, Gibbons JM, Milner-Gulland EJ. 2008a. Testing the use of interviews as a tool for monitoring trends in the harvesting of wild species. Journal of Applied Ecology 45:1205-1212.

Jones JPG, Andriamarovololona MM, Hockley N, Gibbons JM, Milner-Gulland EJ. 2008 b. Testing the use of interviews as a tool for monitoring trends in the harvesting of wild species. Journal of Applied Ecology 45:1205-1212. DOI: 10.1111/j.13652664.2008.01487.x. 
931 Jorge, M., Peres CA. 2005. Population Density and Home Range Size of Red-Rumped Agoutis

932 (Dasyprocta leporina) within and outside a Natural Brazil Nut Stand in Southeastern

933

934

935

936

937

938

939

940

941

942

943

944

945

946

947

948

949

950

951

952

Amazonia . Biotropica 37:317-321. DOI: 10.1111/j.1744-7429.2005.00041.x

Kery M, Royle JA. 2015. Applied Hierarchical Modeling in Ecology: Analysis of Distribution, Abundance and Species Richness in R and BUGS: Volume 1: Dynamic and Advanced Models. Academic Press.

Keuroghlian A, Eaton DP, Longland WS. 2004. Area use by white-lipped and collared peccaries (Tayassu pecari and Tayassu tajacu) in a tropical forest fragment. Biological Conservation 120:411-425. DOI: 10.1016/j.biocon.2004.03.016.

Kingsbury ND. 2001. Impacts of Land Use and Cultural Change in a Fragile Environment: Indigenous Acculturation and Deforestation in Kavanayén, Gran Sabana, Venezuela. Interciencia 26:327-336.

Knoop SB, Morcatty TQ, El Bizri HR, Cheyne SM. 2020. Age, Religion, and Taboos Influence Subsistence Hunting by Indigenous People of the Lower Madeira River, Brazilian Amazon. Journal of Ethnobiology 40:131-148. DOI: https://doi.org/10.2993/0278-0771-40.2.131.

Levis C, Costa FRC, Bongers F, Peña-Claros M, Clement CR, Junqueira AB, Ter Steege H. 2017. Persistent effects of pre-Columbian plant domestication on Amazonian forest composition. Science 358:925-931. DOI: 10.1126/science.aan8347.

Lewis SL, Edwards DP, Galbraith D. 2015. Increasing human dominance of tropical forests. Science 349:827-832. DOI: 10.1126/science.aaa9932.

Lim BK, Engstrom MD, Ochoa J, Ochoa J. 2005. MAMMALS. Bulletin of the Biological Society of Washington 13:77-92. DOI: 10.2988/0097-0298(2005)13[77:M]2.0.CO;2.

Peer] reviewing PDF | (2020:07:51031:2:1:NEW 20 May 2021) 
953 Linares OF. 1976. "Garden hunting" in the American tropics. Human Ecology 4:331-349. DOI: $954 \quad 10.1007 / \mathrm{BF} 01557917$.

955 Linares O. 1998. Mamiferos de Venezuela. Caracas Venezuela: Sociedad Conservacionista $956 \quad$ Audubon de Venezuela.

957 Lozada JR. 2019. The Orinoco Mining Arc: a historical perspective. Gold Bulletin 52:153-163.

958 DOI: $10.1007 / \mathrm{s} 13404-019-00261-1$.

959 MacKenzie DI, Bailey LL. 2004. Assessing the fit of site-occupancy models. Journal of 960 Agricultural, Biological, and Environmental Statistics 9:300-318. DOI:

961

962

963

964

Madhusudan MD, Karanth KU. 2002. Local hunting and the conservation of large mammals in India. Ambio 31:49-54. DOI: 10.1579/0044-7447-31.1.49.

Mansutti A. 1990. Los Piaroa y su Territorio. Caracas.

Mason NWH, Mouillot D. 2013. Functional Diversity Measures. Elsevier Ltd. DOI: 10.1016/B978-0-12-384719-5.00356-7.

Mazerolle MJ. 2020. AICcmodavg: Model selection and multimodel inference based on (Q)AIC(c).

Naughton-Treves L. 2002. Wild animals in the garden: Conserving wildlife in amazonian agroecosystems. Annals of the Association of American Geographers 92:488-506. DOI: 10.1111/1467-8306.00301.

Naughton-Treves L, Mena JL, Treves A, Alvarez N, Radeloff VC. 2003. Wildlife Survival Beyond Park Boundaries: The Impact of Slash-and-Burn Agriculture and Hunting on 
974

975

976

977

978

979

980

981

982

983

984

985

986

987

988

989

990

991

992

993

Mammals in Tambopata, Peru. Conservation Biology 17:1106-1117. DOI: 10.1046/j.15231739.2003.02045.x.

Nuno A, St. John FAV. 2014. How to ask sensitive questions in conservation: A review of specialized questioning techniques. Biological Conservation 189:5-15. DOI: 10.1016/j.biocon.2014.09.047.

O’Brien TG, Baillie JEM, Krueger L, Cuke M. 2010. The wildlife picture index: Monitoring top trophic levels. Animal Conservation 13:335-343. DOI: 10.1111/j.1469-1795.2010.00357.x.

Peres CA. 2000. Effects of subsistence hunting on vertebrate community structure in Amazonian forests. Conservation Biology 14:240-253. DOI: 10.1046/j.1523-1739.2000.98485.x.

Phillips O, Gentry AH, Reynel C, Wilkin P, Galvez-Durand B C. 1994. Quantitative Ethnobotany and Amazonian Conservation. Conservation Biology 8:225-248. DOI: 10.1046/j.1523-1739.1994.08010225.x.

Redford KH. 1992. The Empty of neotropical forest where the vegetation still appears intact. BioScience 42:412-422.

Richard-Hansen C, Davy D, Longin G, Gaillard L, Renoux F, Grenand P, Rinaldo R. 2019. Hunting in French Guiana Across Time, Space and Livelihoods. Frontiers in Ecology and Evolution 7. DOI: 10.3389/fevo.2019.00289.

Rios E, McGowan P, Collar N, Maíra B, R. CG, Fabio O, Manoel S-F, Bernardo C. 2020. Which is worse for the red-billed curassow: habitat loss or hunting pressure? Oryx:1-9. DOI: $10.1017 / \mathrm{S} 0030605319000711$. 
994 Ripple WJ, Abernethy K, Betts MG, Chapron G, Dirzo R, Galetti M, Levi T, Lindsey PA, 995 Macdonald DW, Machovina B, Newsome TM, Peres CA, Wallach AD, Wolf C. 2016. 996 Bushmeat hunting and extinction risk to the world's mammals. Royal Society Open Science 997 3. DOI: $10.1098 /$ rsos. 160498.

998

999

1000

1001

1002

1003

1004

1005

1006

1007

1008

1009

1010

1011

1012

1013

1014

Robinson JG, Bennett EL. 2004. Having your wildlife and eating it too: An analysis of hunting sustainability across tropical ecosystems. Animal Conservation 7:397-408. DOI: $10.1017 /$ S1367943004001532.

Rodríguez JP. 2000. Impact of the Venezuelan economic crisis on wild populations of animals and plants. Biological Conservation 96:151-159. DOI: 10.1016/S0006-3207(00)00061-6.

Rodríguez I. 2004. Conocimiento indígena vs científico: el conflicto por el uso del fuego en el parque nacional Canaima, Venezuela. Interciencia 29:121-129.

Rodríguez JP, Garcia-Rawlins A, Rojas-Suárez F. 2015. Libro Rojo de la Fauna Venezolana. Caracas, Venezuela: Provita y Fundación Empresas Polar.

Roopsind A, Caughlin TT, Sambhu H, Fragoso JMV, Putz FE. 2017. Logging and indigenous hunting impacts on persistence of large Neotropical animals. Biotropica 49:565-575. DOI: $10.1111 /$ btp. 12446.

Rovero F, Ahumada J, Jansen PA, Sheil D, Alvarez P, Boekee K, Espinosa S, Lima MGM, Martin EH, O’Brien TG, Salvador J, Santos F, Rosa M, Zvoleff A, Sutherland C, Tenan S. 2020. A standardized assessment of forest mammal communities reveals consistent functional composition and vulnerability across the tropics. Ecography 43:75-84. DOI: 10.1111/ecog.04773. 
1015 Royle JA. 2006. Site occupancy models with heterogeneous detection probabilities. Biometrics 1016 62:97-102. DOI: 10.1111/j.1541-0420.2005.00439.x.

1017 Royle JA, Nichols JD. 2003. Estimating abundance from repeated presence-absence data or point 1018 counts. Ecology 84:777-790. DOI: 10.1890/0012-9658(2003)084[0777:EAFRPA]2.0.CO;2.

1019 Rull V, Montoya E, Nogué S, Vegas-Vilarrúbia T, Safont E. 2013. Ecological palaeoecology in 1020 the neotropical Gran Sabana region: Long-term records of vegetation dynamics as a basis 1021 for ecological hypothesis testing. Perspectives in Plant Ecology, Evolution and Systematics $1022 \quad$ 15:338-359. DOI: 10.1016/j.ppees.2013.07.004.

1023 Saatchi S, Houghton RA, Dos Santos Alvalá RC, Soares J V., Yu Y. 2007. Distribution of 1024 aboveground live biomass in the Amazon basin. Global Change Biology 13:816-837. DOI: 1025

Scotson L, Fredriksson G, Ngoprasert D, Wong WM, Fieberg J. 2017. Projecting range-wide sun 10.1111/j.1365-2486.2007.01323.x.

1029

1030 1031 1032 1033 1034 1035 bear population trends using tree cover and camera-trap bycatch data. PLOS ONE 12:1-18. DOI: 10.1371/journal.pone.0185336.

Señaris JC, Lew D, Lasso C. 2009. Biodiversidad del Parque Nacional Canaima: bases técnicas para la conservación de la Guayana venezolana. Caracas, Venezuela: Fundación La Salle de Ciencias Naturales and The Nature Conservancy.

Sletto B, Rodriguez I. 2013. Burning, fi re prevention and landscape productions among the Pemon, Gran Sabana, Venezuela: Toward an intercultural approach to wildland fi re management in Neotropical Savannas. Journal of Environmental Management 115:155166. DOI: 10.1016/j.jenvman.2012.10.041. 
1036 Smith DA. 2005. Garden game: Shifting cultivation, indigenous hunting and wildlife ecology in 1037 western Panama. Human Ecology 33:505-537. DOI: 10.1007/s10745-005-5157-Y.

1038 Smith DA. 2008. The spatial patterns of indigenous wildlife use in western Panama: Implications 1039 for conservation management. Biological Conservation 141:925-937. DOI:

$1040 \quad$ 10.1016/j.biocon.2007.12.021.

1041 SOS-Orinoco. 2018. Situación Actual de la Minería Aurífera en el Parque Nacional Canaima: 1042 Sitio de Patrimonio Mundial en Venezuela. :70.

1043 Stachowicz I, Paris JRF, Quiroga-Carmona M, Moran L, Lozano C. 2020. Baseline for 1044 monitoring and habitat use of medium to large non-volant mammals in Gran Sabana, 1045 Venezuela. Therya 11. DOI: 10.12933/therya-20-891.

1046 1047 1048 1049 1050 1051 1052 1053 1054 1055 1056 1057 ter Steege H, Prado PI, Lima RAF d., Pos E, de Souza Coelho L, de Andrade Lima Filho D, Salomão RP, Amaral IL, de Almeida Matos FD, Castilho C V., Phillips OL, Guevara JE, de Jesus Veiga Carim M, Cárdenas López D, Magnusson WE, Wittmann F, Martins MP, Sabatier D, Irume MV, da Silva Guimarães JR, Molino JF, Bánki OS, Piedade MTF, Pitman NCA, Ramos JF, Monteagudo Mendoza A, Venticinque EM, Luize BG, Núñez Vargas P, Silva TSF, de Leão Novo EMM, Reis NFC, Terborgh J, Manzatto AG, Casula KR, Honorio Coronado EN, Montero JC, Duque A, Costa FRC, Castaño Arboleda N, Schöngart J, Zartman CE, Killeen TJ, Marimon BS, Marimon-Junior BH, Vasquez R, Mostacedo B, Demarchi LO, Feldpausch TR, Engel J, Petronelli P, Baraloto C, Assis RL, Castellanos H, Simon MF, de Medeiros MB, Quaresma A, Laurance SGW, Rincón LM, Andrade A, Sousa TR, Camargo JL, Schietti J, Laurance WF, de Queiroz HL, Nascimento HEM, Lopes MA, de Sousa Farias E, Magalhães JLL, Brienen R, Aymard C GA, Revilla JDC, Vieira ICG, 
1058

1059

1060

1061

1062

1063

1064

1065

1066

1067

1068

1069

1070

1071

1072

1073

1074

1075

1076

1077

1078

1079

Cintra BBL, Stevenson PR, Feitosa YO, Duivenvoorden JF, Mogollón HF, Araujo-

Murakami A, Ferreira LV, Lozada JR, Comiskey JA, de Toledo JJ, Damasco G, Dávila N,

Lopes A, García-Villacorta R, Draper F, Vicentini A, Cornejo Valverde F, Lloyd J, Gomes

VHF, Neill D, Alonso A, Dallmeier F, de Souza FC, Gribel R, Arroyo L, Carvalho FA, de Aguiar DPP, do Amaral DD, Pansonato MP, Feeley KJ, Berenguer E, Fine PVA, Guedes

MC, Barlow J, Ferreira J, Villa B, Peñuela Mora MC, Jimenez EM, Licona JC, Cerón C, Thomas R, Maas P, Silveira M, Henkel TW, Stropp J, Paredes MR, Dexter KG, Daly D, Baker TR, Huamantupa-Chuquimaco I, Milliken W, Pennington T, Tello JS, Pena JLM, Peres CA, Klitgaard B, Fuentes A, Silman MR, Di Fiore A, von Hildebrand P, Chave J, van Andel TR, Hilário RR, Phillips JF, Rivas-Torres G, Noronha JC, Prieto A, Gonzales T, de Sá Carpanedo R, Gonzales GPG, Gómez RZ, de Jesus Rodrigues D, Zent EL, Ruschel AR, Vos VA, Fonty É, Junqueira AB, Doza HPD, Hoffman B, Zent S, Barbosa EM, Malhi Y, de Matos Bonates LC, de Andrade Miranda IP, Silva N, Barbosa FR, Vela CIA, Pinto LFM, Rudas A, Albuquerque BW, Umaña MN, Carrero Márquez YA, van der Heijden G, Young KR, Tirado M, Correa DF, Sierra R, Costa JBP, Rocha M, Vilanova Torre E, Wang O, Oliveira AA, Kalamandeen M, Vriesendorp C, Ramirez-Angulo H, Holmgren M, Nascimento MT, Galbraith D, Flores BM, Scudeller VV, Cano A, Ahuite Reategui MA, Mesones I, Baider C, Mendoza C, Zagt R, Urrego Giraldo LE, Ferreira C, Villarroel D, Linares-Palomino R, Farfan-Rios W, Farfan-Rios W, Casas LF, Cárdenas S, Balslev H, Torres-Lezama A, Alexiades MN, Garcia-Cabrera K, Valenzuela Gamarra L, Valderrama Sandoval EH, Ramirez Arevalo F, Hernandez L, Sampaio AF, Pansini S, Palacios Cuenca W, de Oliveira EA, Pauletto D, Levesley A, Melgaço K, Pickavance G. 2020. Biased- 
1080

1081

1082

1083

1084

1085

1086

1087

1088

1089

1090

1091

1092

1093

1094

1095

1096

1097

1098

1099

corrected richness estimates for the Amazonian tree flora. Scientific Reports 10:1-13. DOI: $10.1038 / \mathrm{s} 41598-020-66686-3$.

Symonds MRE, Moussalli A. 2011. A brief guide to model selection, multimodel inference and model averaging in behavioural ecology using Akaike's information criterion. Behavioral Ecology and Sociobiology 65:13-21. DOI: 10.1007/s00265-010-1037-6.

Urbina L. 1979. Adaptación ecológico-cultural de los Pemón-Arekuna: el caso de Tuauken. Instituto Venezolano de Investigaciones Científicas.

Vetter D, Hansbauer MM, Végvári Z, Storch I. 2011. Predictors of forest fragmentation sensitivity in Neotropical vertebrates: A quantitative review. Ecography 34:1-8. DOI: 10.1111/j.1600-0587.2010.06453.x

van Vliet N, Antunes AP, Constantino P de AL, Gómez J, Santos-Fita D, Sartoretto E. 2019. Frameworks regulating hunting for meat in tropical countries leave the sector in the Limbo. Frontiers in Ecology and Evolution 7. DOI: 10.3389/fevo.2019.00280.

Voicu M-C. 2011. Using the snowball method in market research on hidden populations. Challenges of the Knowledge Society 1:1341-1351.

Warner K. 1991. Shifting cultivators - Local technical knowledge and natural resource management in the humid tropics. FAO Com-munity Forestry Note, 8, Rome, Italy.

Weckel M, Giuliano W, Silver S. 2006. Jaguar (Panthera onca) feeding ecology: Distribution of predator and prey through time and space. Journal of Zoology 270:25-30. DOI: 10.1111/j.1469-7998.2006.00106.x. 
1100 Weinbaum KZ, Brashares JS, Golden CD, Getz WM. 2013. Searching for sustainability: Are 1101 assessments of wildlife harvests behind the times? Ecology Letters 16:99-111. DOI: $1102 \quad 10.1111 /$ ele. 12008.

1103 Zapata-Ríos G, Urgilés C, Suárez E. 2009. Mammal hunting by the Shuar of the Ecuadorian 1104 Amazon: Is it sustainable? Oryx 43:375-385. DOI: 10.1017/S0030605309001914.

1105 Zent S. 1992. Historical and ethnographic ecology of the Upper Cuao River Wothiha: clues for 1106 an interpretation of native Guianese social organization. Columbia University, New York.

1107 Zent S. 1997. Piaroa and the Cracidae: Game management under shifting cultivation. In: Stuard 1108 D. Strahl et al. ed. The Cracidae; their biology and conservation. Handcock House Publishers, 1109 177-194.

1110 


\section{Table $\mathbf{1}$ (on next page)}

Nonvolant medium, large mammal and bird species detected during the camera trap survey.

Scientific, common names and names in Arekuna (Pemón dialect) are provided for each species. Frequency of detection index, total number of detections for species and survey method: are shown. $\mathrm{CT}=$ camera trapping, $\mathrm{TRK}=$ tracking, INT= interviews with local Pemón communities. IUCN Red List category based on country assessment (Rodríguez 2015) and dietary group based on Linares (1998) and Eisenberg (1989) are shown for mammals (herb herbivorous, omni - omnivorous, carn - carnivorous and inse - insectivorous). 


\begin{tabular}{|c|c|c|c|c|c|c|c|}
\hline Common name & Scientific name & $\begin{array}{l}\text { Species' } \\
\text { name in } \\
\text { Arekuna }\end{array}$ & $\begin{array}{l}\text { Frequency } \\
\text { of } \\
\text { detection } \\
\text { (FD) }\end{array}$ & $\begin{array}{l}\text { Number } \\
\text { of } \\
\text { detection } \\
\text { events } \\
\text { (D) }\end{array}$ & $\begin{array}{l}\text { Survey } \\
\text { method }\end{array}$ & $\begin{array}{c}\text { IUCN Red } \\
\text { List } \\
\text { Category }\end{array}$ & $\begin{array}{l}\text { Dietary } \\
\text { group }\end{array}$ \\
\hline \multicolumn{8}{|l|}{ ARTIODACTYLA } \\
\hline Red Brocket & $\begin{array}{l}\text { Mazama } \\
\text { americana } \\
\text { (Erxleben 1777) }\end{array}$ & kutsari & 0.44 & 20 & $\begin{array}{l}\text { CT,TRK, } \\
\text { INT }\end{array}$ & DD & herb \\
\hline Gray Brocket & $\begin{array}{l}\text { Mazama } \\
\text { gouazoubira } \\
\text { (G.Fischer 1814) }\end{array}$ & kariyawku & 1.03 & 47 & $\begin{array}{l}\text { CT,TRK, } \\
\text { INT }\end{array}$ & LC & herb \\
\hline White-tailed Deer & $\begin{array}{l}\text { Odocoileus } \\
\text { virginianus } \\
\text { (Zimmermann, } \\
\text { 1780) }\end{array}$ & waikín & 0.09 & 4 & $\begin{array}{l}\text { CT,TRK, } \\
\text { INT }\end{array}$ & LC & herb \\
\hline Collared Peccary & \begin{tabular}{|l} 
Pecari tajacu \\
(Linnaeus 1758)
\end{tabular} & poyinke & 0.04 & 2 & $\begin{array}{l}\text { CT,TRK, } \\
\text { INT }\end{array}$ & LC & omni \\
\hline $\begin{array}{r}\text { White-lipped } \\
\text { Peccary }\end{array}$ & $\begin{array}{l}\text { Tayassu pecari } \\
\text { (Link 1795) }\end{array}$ & pakirá & 0.04 & 2 & CT, INT & VU & omni \\
\hline \multicolumn{8}{|l|}{ CARNIVORA } \\
\hline Margay & $\begin{array}{l}\text { Leopardus wiedii } \\
\text { (Schinz 1821) }\end{array}$ & - & 0.04 & 2 & CT & VU & carn \\
\hline Ocelot & $\begin{array}{l}\text { Leopardus } \\
\text { pardalis } \\
\text { (Linnaeus 1758) }\end{array}$ & kaukan & 0.33 & 15 & $\begin{array}{l}\text { CT,TRK, } \\
\text { INT }\end{array}$ & LC & carn \\
\hline Jaguar & \begin{tabular}{|l} 
Panthera onca \\
(Linnaeus 1758)
\end{tabular} & temenen & 0.31 & 14 & $\begin{array}{l}\text { CT,TRK, } \\
\text { INT }\end{array}$ & VU & carn \\
\hline Puma & \begin{tabular}{|l} 
Puma concolor \\
(Linnaeus 1771)
\end{tabular} & kusariwara & 0.24 & 11 & $\begin{array}{l}\text { CT,TRK, } \\
\text { INT }\end{array}$ & LC & carn \\
\hline Crab-eating Fox & $\begin{array}{l}\text { Cerdocyon thous } \\
\text { (Linnaeus, 1766) }\end{array}$ & maikan & 0.97 & 44 & $\begin{array}{c}\text { CT,TRK, } \\
\text { INT }\end{array}$ & LC & omni \\
\hline Tayra & \begin{tabular}{|l} 
Eira barbara \\
(Linnaeus 1758)
\end{tabular} & yeruena & 0.46 & 21 & CT, INT & LC & carn \\
\hline $\begin{array}{r}\text { South American } \\
\text { Coati }\end{array}$ & \begin{tabular}{|l} 
Nasua nasua \\
(Linnaeus 1766)
\end{tabular} & kuachi & 0.18 & 8 & CT, INT & LC & omni \\
\hline \multicolumn{8}{|l|}{ CINGULATA } \\
\hline $\begin{array}{r}\text { Greater Long- } \\
\text { nosed Armadillo }\end{array}$ & $\begin{array}{l}\text { Dasypus kappleri } \\
\text { (Krauss 1862) }\end{array}$ & - & 0.75 & 34 & CT, TRK & LC & inse \\
\hline $\begin{array}{r}\text { Nine-banded } \\
\text { Armadillo }\end{array}$ & $\begin{array}{l}\text { Dasypus } \\
\text { novemcinctus } \\
\text { (Linnaeus 1758) }\end{array}$ & muruk & 0.42 & 19 & $\begin{array}{l}\text { CT,TRK, } \\
\text { INT }\end{array}$ & LC & inse \\
\hline $\begin{array}{l}\text { Southern Naked- } \\
\text { Tailed Armadillo }\end{array}$ & $\begin{array}{l}\text { Cabassous } \\
\text { unicinctus } \\
\text { (Linnaeus 1758) }\end{array}$ & - & 0.04 & 2 & CT & LC & inse \\
\hline
\end{tabular}




\begin{tabular}{|c|c|c|c|c|c|c|c|}
\hline Giant Armadillo & $\begin{array}{l}\text { Priodontes } \\
\text { maximus (Kerr } \\
1792 \text { ) }\end{array}$ & mauraimu & 0.18 & 8 & $\begin{array}{l}\text { CT,TRK, } \\
\text { INT }\end{array}$ & EN & inse \\
\hline \multicolumn{8}{|l|}{ PERISSODACYLA } \\
\hline $\begin{array}{r}\text { South American } \\
\text { Tapir }\end{array}$ & \begin{tabular}{|l} 
Tapirus terrestris \\
(Linnaeus 1758)
\end{tabular} & maikuri & 0.31 & 14 & $\begin{array}{l}\text { CT,TRK, } \\
\text { INT }\end{array}$ & VU & herb \\
\hline \multicolumn{8}{|l|}{ DIDEPHIMORPHIA } \\
\hline $\begin{array}{l}\text { Guianan White- } \\
\text { eared Opossum }\end{array}$ & $\begin{array}{l}\text { Didelphis } \\
\text { imperfecta } \\
\text { (Mondolfi and } \\
\text { Pérez- } \\
\text { Hernandez } \\
\text { 1984) }\end{array}$ & - & 0.31 & 14 & CT & LC & omni \\
\hline Common Opossum & $\begin{array}{l}\text { Didelphis } \\
\text { marsupialis } \\
\text { (Linnaeus 1758) }\end{array}$ & awaré & 0.04 & 2 & CT, INT & LC & omni \\
\hline \multicolumn{8}{|l|}{ PILOSA } \\
\hline $\begin{array}{l}\text { Southern } \\
\text { Tamandua }\end{array}$ & $\begin{array}{l}\text { Tamandua } \\
\text { tetradactyla } \\
\text { (Linnaeus 1758) }\end{array}$ & woiwo & 0.13 & 6 & CT, INT & LC & omni \\
\hline \multirow{2}{*}{ Giant Anteater } & $\begin{array}{l}\text { Myrmecophaga } \\
\text { tridactyla }\end{array}$ & \multirow{2}{*}{ wareme } & \multirow[t]{2}{*}{0.33} & \multirow[t]{2}{*}{15} & \multirow{2}{*}{$\begin{array}{l}\text { CT,TRK, } \\
\text { INT }\end{array}$} & \multirow[t]{2}{*}{ VU } & \multirow[t]{2}{*}{ insec } \\
\hline & (Linnaeus 1758 & & & & & & \\
\hline \multicolumn{8}{|l|}{ RODENTIA } \\
\hline Lowland Paca & $\begin{array}{l}\text { Cuniculus paca } \\
\text { (Linnaeus 1766) }\end{array}$ & uraná & 5.83 & 265 & $\begin{array}{c}\text { CT,TRK, } \\
\text { INT }\end{array}$ & LC & herb \\
\hline $\begin{array}{r}\text { Red-rumped } \\
\text { Agouti }\end{array}$ & $\begin{array}{l}\text { Dasyprocta } \\
\text { leporina } \\
\text { (Linnaeus 1758) }\end{array}$ & akuri & 4.2 & 191 & $\begin{array}{c}\text { CT,TRK, } \\
\text { INT }\end{array}$ & LC & herb \\
\hline Capybara & $\begin{array}{l}\text { Hydrochoeris } \\
\text { hydrochaeris } \\
\text { (Linnaeus 1766) }\end{array}$ & parwena & 0.07 & 3 & $\begin{array}{c}\text { CT,TRK, } \\
\text { INT }\end{array}$ & LC & herb \\
\hline \multicolumn{8}{|l|}{ PRIMATES } \\
\hline $\begin{array}{r}\text { Wedge-capped } \\
\text { Capuchin }\end{array}$ & $\begin{array}{l}\text { Cebus olivaceus } \\
\text { (Schomburgk, } \\
1848 \text { ) }\end{array}$ & ibarakao & 0.18 & 8 & $\begin{array}{l}\text { CT,TRK, } \\
\text { INT }\end{array}$ & LC & omniv \\
\hline \multirow{2}{*}{$\begin{array}{r}\text { Guyanan Red } \\
\text { Howler }\end{array}$} & $\begin{array}{l}\text { Alouatta } \\
\text { macconnelli* }\end{array}$ & \multirow[t]{2}{*}{ arauta } & \multirow[t]{2}{*}{ - } & - & \multirow{2}{*}{$\begin{array}{l}\text { TRK, } \\
\text { INT }\end{array}$} & \multirow[t]{2}{*}{ LC } & \multirow[t]{2}{*}{ herb } \\
\hline & (Linnaeus 1766) & & & & & & \\
\hline \multicolumn{8}{|c|}{ BIRDS } \\
\hline Pectoral sparrow & $\begin{array}{l}\text { Arremon } \\
\text { taciturnus }\end{array}$ & & 0.18 & 8 & CT, INT & LC & \\
\hline Savanna hawk & $\begin{array}{l}\text { Buteogallus } \\
\text { meridionalis }\end{array}$ & woroiwo & 0.02 & 1 & $\begin{array}{l}\text { CT, } \\
\text { TRK, }\end{array}$ & LC & \\
\hline
\end{tabular}




\begin{tabular}{|c|c|c|c|c|c|c|}
\hline & & & & & INT & \\
\hline Turkey vulture & Cathartes aura & kurüm & 0.04 & 2 & $\begin{array}{c}\text { CT, } \\
\text { TRK, } \\
\text { INT }\end{array}$ & LC \\
\hline Black curassow & Crax alector & pauwi & 1.06 & 48 & $\begin{array}{l}\text { CT, } \\
\text { TRK, } \\
\text { INT }\end{array}$ & VU \\
\hline Tinamous & Crypturellus spp. & & 0.04 & 2 & $\begin{array}{c}\text { CT, } \\
\text { TRK, } \\
\text { INT }\end{array}$ & \\
\hline $\begin{array}{r}\text { Variegated } \\
\text { tinamou }\end{array}$ & $\begin{array}{l}\text { Crypturellus } \\
\text { variegatus }\end{array}$ & & 0.15 & 7 & CT & LC \\
\hline Little tinamou & Crypturellus soui & churima & 0.24 & 11 & $\mathrm{CT}, \mathrm{INT}$ & LC \\
\hline Ruddy quail-dove & $\begin{array}{l}\text { Geotrygon } \\
\text { montana }\end{array}$ & & 0.02 & 1 & CT & LC \\
\hline Grey-fronted dove & $\begin{array}{l}\text { Leptotila } \\
\text { rufaxilla }\end{array}$ & wakuma & 1.5 & 68 & $\begin{array}{c}\text { CT, } \\
\text { TRK, } \\
\text { INT }\end{array}$ & LC \\
\hline Green ibis & $\begin{array}{l}\text { Mesembrinibis } \\
\text { cayennensis }\end{array}$ & & 0.02 & 1 & $\begin{array}{c}\text { CT, } \\
\text { TRK, } \\
\text { INT }\end{array}$ & LC \\
\hline $\begin{array}{r}\text { Tropical } \\
\text { mockingbird }\end{array}$ & Mimus gilvus & paraura & 0.24 & 11 & CT & LC \\
\hline $\begin{array}{l}\text { Rufous-winged } \\
\text { ground cuckoo }\end{array}$ & $\begin{array}{l}\text { Neomorphus } \\
\text { rufipennis }\end{array}$ & & 0.02 & 1 & CT & LC \\
\hline Spix's guan & $\begin{array}{l}\text { Penelope } \\
\text { jacquacu }\end{array}$ & wora & 0.18 & 8 & $\begin{array}{c}\text { CT, } \\
\text { TRK, } \\
\text { INT }\end{array}$ & LC \\
\hline Great tinamou & Tinamus major & marú & 0.53 & 24 & $\begin{array}{l}\text { CT, } \\
\text { TRK, } \\
\text { INT }\end{array}$ & NT \\
\hline $\begin{array}{r}\text { White-necked } \\
\text { thrush }\end{array}$ & Turdus albicollis & & 0.73 & 33 & CT & LC \\
\hline
\end{tabular}

$1 *$ species documented only by vocalization and interviews with local communities. 


\section{Table 2 (on next page)}

Indices of hunting importance (Hv) and hunting preference (Pv) reported for the Pemón communities.

Mammal species are ordered by diet groups, birds are presented in one group as they have a mixed diet. 


\begin{tabular}{|c|c|c|c|c|c|}
\hline Diet group & Species & Common name & $\mathrm{Hv}$ & $\mathrm{Pv}$ & $\begin{array}{l}\text { Red List of } \\
\text { species }\end{array}$ \\
\hline \multicolumn{6}{|c|}{ Mammals } \\
\hline \multirow[t]{2}{*}{ Insectivorous } & $\begin{array}{l}\text { Dasypus kappleri (Krauss, } \\
\text { 1862) }\end{array}$ & $\begin{array}{l}\text { greater long-nosed } \\
\text { armadillo }\end{array}$ & \multirow{2}{*}{0.244} & & $\mathrm{LC}$ \\
\hline & $\begin{array}{l}\text { Dasypus novemcinctus } \\
\text { (Linnaeus, 1758) }\end{array}$ & $\begin{array}{l}\text { nine-banded } \\
\text { armadillo }\end{array}$ & & & LC \\
\hline Omnivorous & Tayassu pecari (Link, 1795) & $\begin{array}{l}\text { white-lipped } \\
\text { peccary }\end{array}$ & 0.975 & & VU \\
\hline \multirow[t]{6}{*}{ Herbivorous } & $\begin{array}{l}\text { Tapirus terrestris (Linnaeus, } \\
1758 \text { ) }\end{array}$ & $\begin{array}{l}\text { South American } \\
\text { tapir }\end{array}$ & 2.681 & & VU \\
\hline & $\begin{array}{l}\text { Cuniculus paca (Linnaeus, } \\
\text { 1766) }\end{array}$ & lowland paca & 6.336 & 1.218 & $\mathrm{LC}$ \\
\hline & $\begin{array}{l}\text { Dasyprocta leporina } \\
\text { (Linnaeus, 1758) }\end{array}$ & red-rumped agouti & 2.681 & & $\mathrm{LC}$ \\
\hline & $\begin{array}{l}\begin{array}{l}\text { Odocoileus virginianus } \\
\text { (Zimmermann, 1780) }\end{array} \\
\end{array}$ & white-tailed deer & 6.823 & 4.874 & $\mathrm{LC}$ \\
\hline & $\begin{array}{l}\text { Mazama americana } \\
\text { (Erxleben, 1777), }\end{array}$ & red brocket & \multirow{2}{*}{0.731} & & DD \\
\hline & $\begin{array}{l}\text { Mazama gouazoubira (G. } \\
\text { Fischer, 1814) }\end{array}$ & gray brocket & & & LC \\
\hline \multicolumn{6}{|c|}{ Birds } \\
\hline & Tinamus major & \multirow{2}{*}{ great tinamu } & \multirow{2}{*}{1.949} & & \multirow{2}{*}{ NT } \\
\hline & (Gmelin, 1789) & & & & \\
\hline & Crax alector & \multirow{2}{*}{ black curassow } & \multirow{2}{*}{4.630} & \multirow{2}{*}{0.975} & \multirow{2}{*}{ VU } \\
\hline & (Linnaeus, 1766) & & & & \\
\hline & Penelope jacquacu & \multirow{2}{*}{ spix's guan } & \multirow{2}{*}{1.949} & & \multirow{2}{*}{$\mathrm{LC}$} \\
\hline & (Spix, 1825) & & & & \\
\hline
\end{tabular}




\section{Table 3 (on next page)}

Model performance metrics.

The MacKenzie and Bailey (2004) test on the full model including goodness of fit test based on Pearson $\left(\chi^{2}\right)$, estimated dispersion parameter (c-hat) and significant level $(p)$. The relative importance of each detection covariate is represented by the sum of AICC or QAICC weights $(\Sigma \mathrm{AICW})$ of the model containing that variable. Variables with strong level of support ( $\Sigma \mathrm{AICW}$ $>0.6)$ are in bold. 


\begin{tabular}{|c|c|c|c|c|c|c|c|c|c|c|c|}
\hline \multirow[b]{2}{*}{ Species } & \multirow[b]{2}{*}{$\begin{array}{c}\text { Total } \\
\text { detections }\end{array}$} & \multicolumn{3}{|c|}{$\begin{array}{l}\text { MacKenzie and Bailey (2004) test on } \\
\text { full model }\end{array}$} & \multicolumn{3}{|c|}{ Detectability } & \multicolumn{4}{|c|}{ Lambda } \\
\hline & & $\chi^{2}$ & $\mathbf{p}$ & c-hat & effort & tracks_dens & date & tree_buffer & tree_buffer ${ }^{\wedge}$ & dist_conuco & dist_river \\
\hline Dasyprocta leporina & 66 & 1093.79 & 0.715 & 0.521 & 0.98 & 0.42 & 0.29 & 1.00 & - & 0.31 & 0.43 \\
\hline Cuniculus paca & 71 & 966.51 & 0.82 & 0.44 & 0.97 & 0.92 & 0.25 & 0.30 & - & 0.87 & 0.31 \\
\hline Leptotila rufaxilla & 33 & 650.08 & 0.63 & 0.36 & 1.00 & 0.22 & 0.37 & 0.85 & 0.79 & 0.31 & 0.23 \\
\hline Cerdocyon thous & 22 & 1217.31 & 0.44 & 0.59 & 0.42 & 0.26 & 0.23 & 0.54 & - & 0.31 & 0.31 \\
\hline Dasypus novemcinctus & 17 & 956.26 & 0.14 & 1.29 & 0.22 & 0.23 & 0.85 & 0.41 & - & 0.32 & 0.23 \\
\hline Crax alector & 31 & 1098.64 & 0.52 & 0.62 & 0.73 & 0.71 & 0.24 & 0.98 & - & 0.64 & 0.23 \\
\hline Leopardus pardalis & 14 & 1427.13 & 0.13 & 1.77 & 0.24 & 0.25 & 0.23 & 0.35 & - & 0.26 & 0.26 \\
\hline Panthera onca & 12 & 427.28 & 0.35 & 0.85 & 0.23 & 0.26 & 0.24 & 0.68 & - & 0.26 & 0.68 \\
\hline Dasypus kappleri & 25 & 922.37 & 0.47 & 0.76 & 0.65 & 0.49 & 0.46 & 1.00 & - & 0.47 & 0.45 \\
\hline Mazama gouazoubira & 33 & 846.97 & 0.65 & 0.52 & 0.97 & 0.22 & 0.22 & 1.00 & - & 0.57 & 0.30 \\
\hline Didelphis imperfecta & 11 & 292.12 & 0.42 & 0.57 & 0.45 & 0.96 & 0.23 & 0.38 & - & 0.24 & 0.24 \\
\hline Tinamus major & 18 & 319.06 & 0.91 & 0.21 & 0.23 & 0.29 & 0.24 & 0.97 & - & 0.25 & 0.24 \\
\hline Mazama americana & 17 & 242.79 & 0.76 & 0.32 & 1.00 & 0.23 & $\mathbf{0 . 8 8}$ & 0.98 & - & 0.24 & 0.25 \\
\hline Myrmecophaga tridactyla & 13 & 413.17 & 0.32 & 0.83 & 0.48 & 0.60 & 0.23 & 0.35 & - & 0.38 & 0.89 \\
\hline Eira barbara & 16 & 282.14 & 0.70 & 0.41 & 0.24 & 0.22 & 0.23 & 0.87 & 0.23 & 0.84 & 0.24 \\
\hline
\end{tabular}




\section{Table 4 (on next page)}

Regression coefficients ( $\pm \mathrm{SE}$ ) and standardized regression coefficient ( $z$ value) of each variable explaining hunting occurrence in the Gran Sabana 


\begin{tabular}{|c|c|c|c|c|}
\hline & Estimate & $\begin{array}{l}\text { Standard } \\
\text { error }\end{array}$ & $\begin{array}{l}\text { z } \\
\text { value }\end{array}$ & $p$ \\
\hline Intercept & -1.475 & 0.780 & -1.890 & 0.05877 \\
\hline tree_buffer & 0.041 & 0.015 & 2.726 & $0.00641 * *$ \\
\hline dist_river & 0.001 & 0.000 & 1.812 & 0.06998. \\
\hline dist_conuco & 0.000 & 0.000 & -1.276 & 0.202 \\
\hline \multirow[t]{2}{*}{$\begin{array}{l}\text { Null deviance: } 82.108 \\
\text { Residual deviance: } \\
62.604 \\
\text { AIC: } 70.604\end{array}$} & & & & \\
\hline & $\begin{array}{l}\text { Signif. codes: } 0^{* * * \prime} 0.001^{\prime * * \prime} 0.01^{\prime * \prime} \\
0.055^{\prime \prime} 0.1^{\prime \prime} 1\end{array}$ & & & \\
\hline
\end{tabular}

1 


\section{Table 5 (on next page)}

The contingency tables showing preferences for habitat and hunting season among interviewees from the four Pemón communities. 


\begin{tabular}{|l|c|c|c|c|c|c|}
\hline & \multicolumn{3}{|c|}{ Habitat } & \multicolumn{3}{c|}{ Season } \\
\hline Community & Forest & Savanna & Mixed & All year & $\begin{array}{l}\text { Rainy } \\
\text { season }\end{array}$ & No preference \\
\hline Kami & 4 & 1 & 2 & 1 & 2 & 1 \\
\hline Mare Paru & 5 & 0 & 0 & 1 & 5 & 0 \\
\hline Uroy-Uaray & 4 & 5 & 4 & 3 & 2 & 2 \\
\hline Wuarapata & 8 & 3 & 4 & 1 & 10 & 0 \\
\hline & & & & & & $\mathrm{p} \leq 0.129$ \\
\hline
\end{tabular}

1 
Figure 1

Study area in the Gran Sabana, Venezuela showing location of the six blocks surveyed with camera traps and the location of conuco.

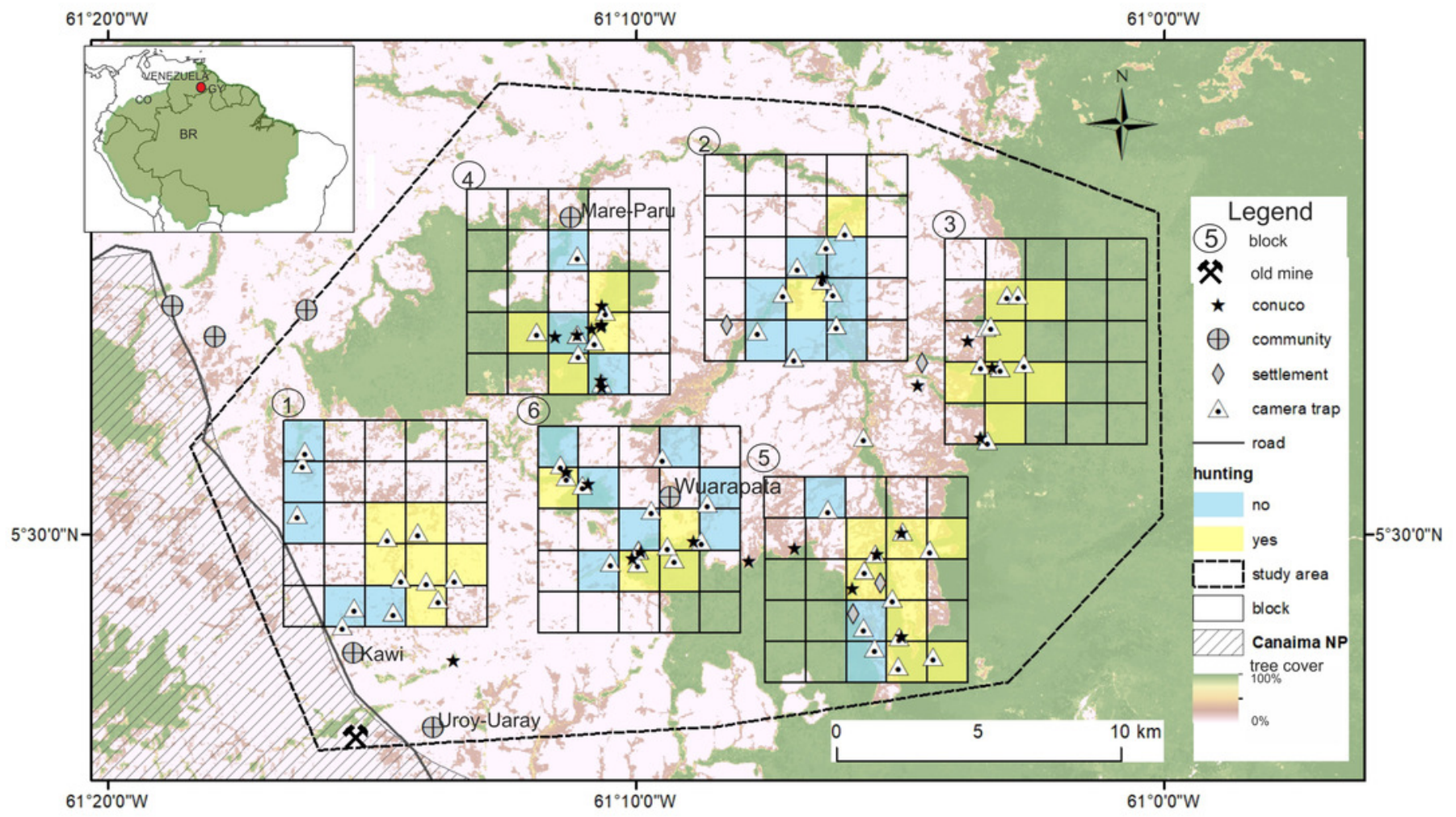


Figure 2

Distribution of predictive variables used to test the Garden Hunting hypothesis.

Values of the percentage of tree cover, distance to conuco and hunting occurrence across sampling units is shown.

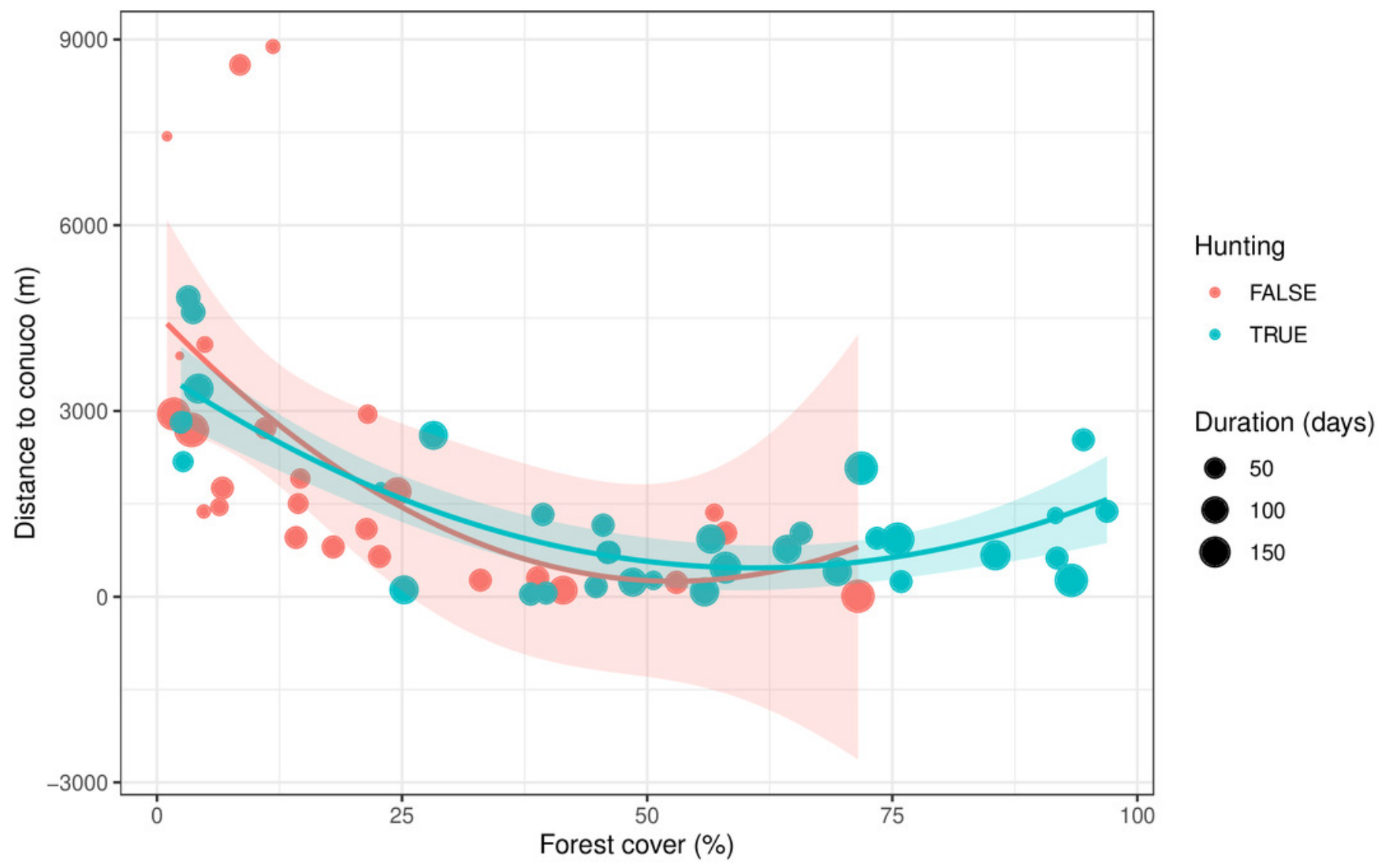




\section{Figure 3}

Hunting technologies used by Pemón.

a) hunter with a shotgun and dog captured by camera traps; b) hunter with a shotgun; c) hunter with a bow captured by camera traps, d) sling. Photo credit b) and d) Izabela Stachowicz.
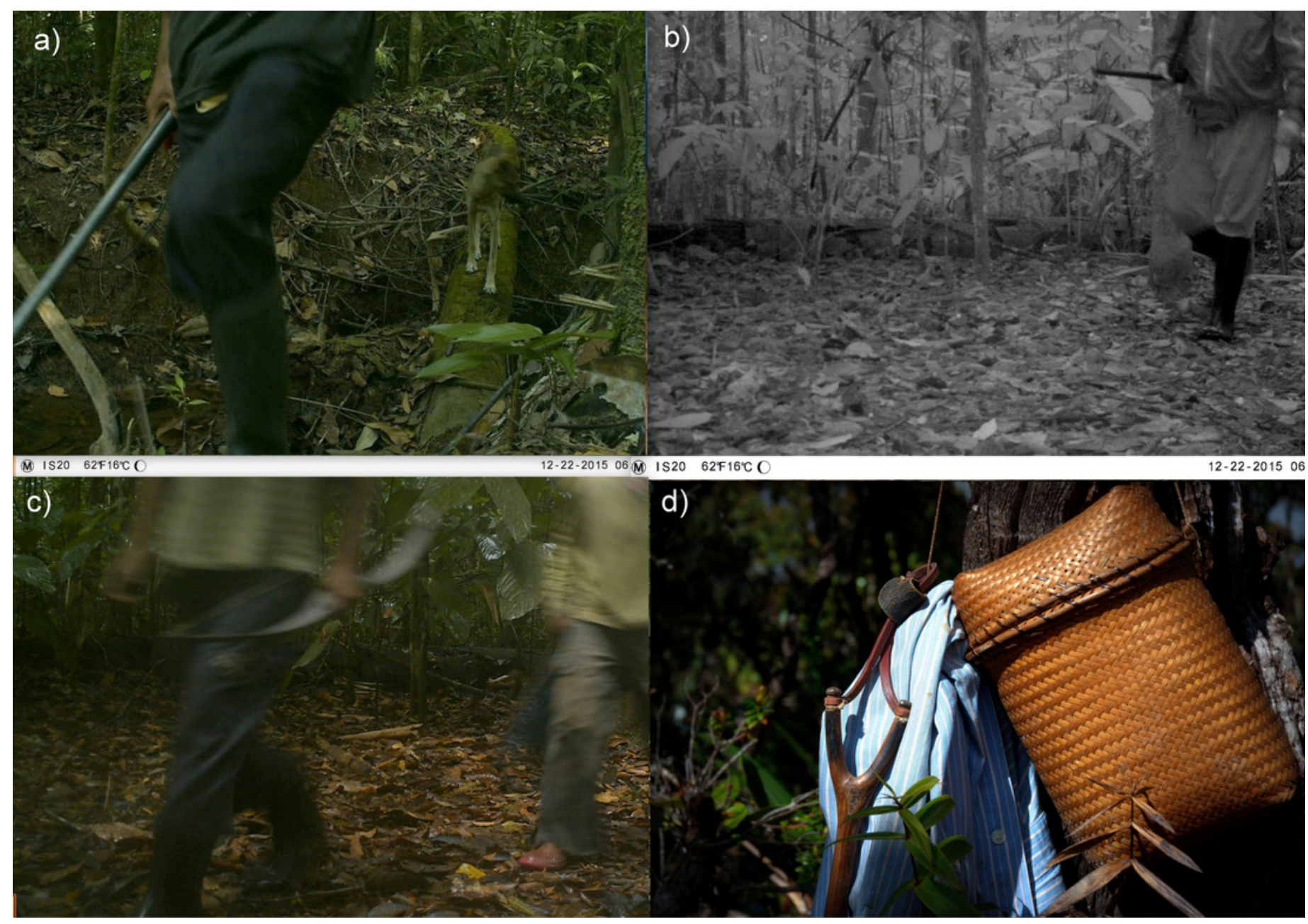
Figure 4

Conditional RN-model averages of the coefficient of distance to conuco.

Error bars are $95 \%$ confidence intervals.

Distance to nearest conuco

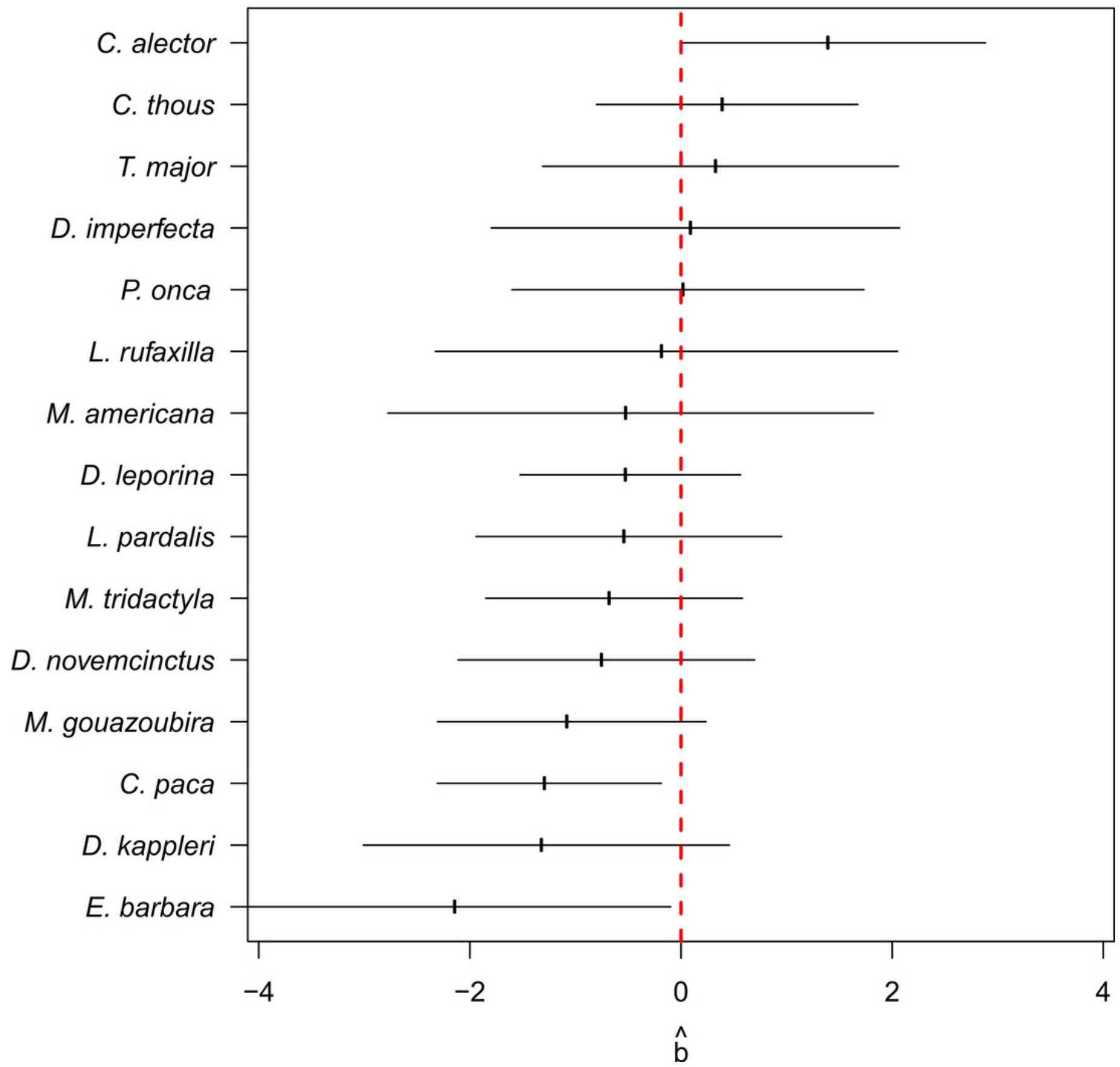


Figure 5

Predicted abundance over sampling units with and without hunting.

Species are ordered from left to right by decreasing $H v$ value, followed by species not reported as game. 


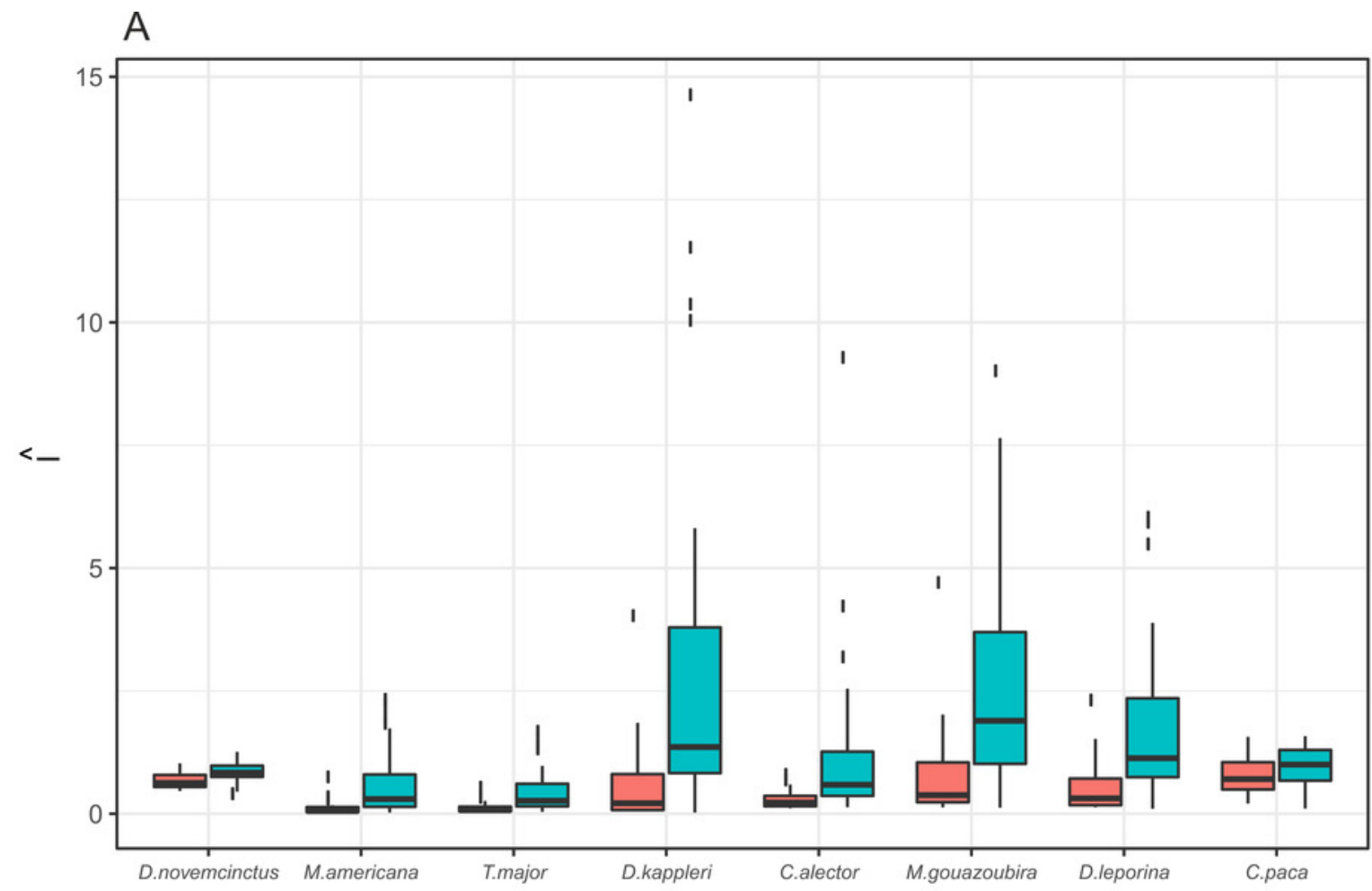

Hunting

官 FALSE

B

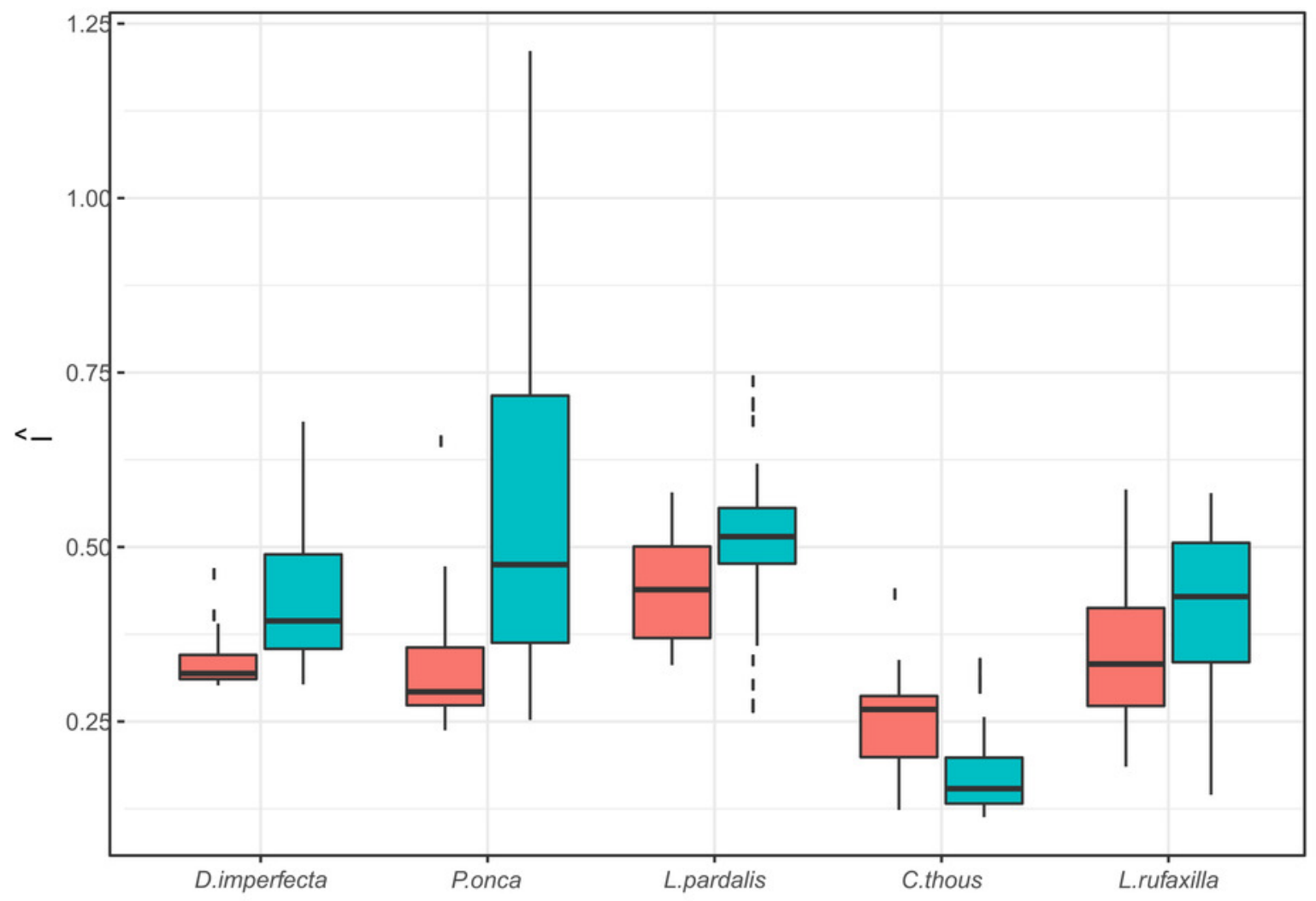

